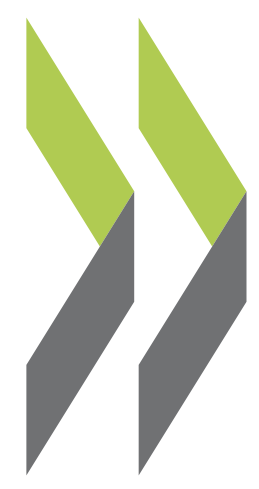

OECD Science, Technology and Industry Working Papers $2018 / 13$

\title{
The productivity-wage premium: Does size still matter in a service economy?
}

Giuseppe Berlingieri, Sara Calligaris, Chiara Criscuolo 


\section{Foreword}

This document has been prepared by Giuseppe Berlingieri, Sara Calligaris and Chiara Criscuolo from the Productivity and Business Dynamics (PBD) Division of the OECD Directorate for Science, Technology and Innovation (STI). This draft has benefited from helpful suggestions and feedback from Dirk Pilat, Alexander Hijzen and Isaac Sorkin, as well as WPIA and CIIE delegates, and seminar participants at the AEA Annual Meeting, OECD, and Paris School of Economics. Rudy Verlhac and Isabelle Desnoyers-James provided excellent assistance with the metadata.

OECD Working Papers should not be reported as representing the official views of the OECD or of its member countries. The opinions expressed and arguments employed are those of the authors.

Working Papers describe preliminary results or research in progress by the authors and are published to stimulate discussion on a broad range of issues on which the OECD works. Comments on Working Papers are welcomed, and may be sent to Directorate for Science, Technology and Innovation, OECD, 2 rue André-Pascal, 75775 Paris Cedex 16, France.

This document, as well as any data and any map included herein, are without prejudice to the status of or sovereignty over any territory, to the delimitation of international frontiers and boundaries and to the name of any territory, city or area.

The release of this working paper has been authorised by Andrew Wyckoff, OECD Director for Science, Technology and Innovation and by Stefano Scarpetta, OECD Director for Employment, Labour and Social Affairs.

A previous version of this document was presented and discussed by the OECD Committee for Industry, Innovation and Entrepreneurship (CIIE) and its Working Party on Industry Analysis (WPIA).

Note to Delegations:

An earlier version of this document is also available on OLIS with the cote:

DSTI/CIIE(2017)15

\section{(C) OECD 2018}

You can copy, download or print OECD content for your own use, and you can include excerpts from OECD publications, databases and multimedia products in your own documents, presentations, blogs, websites and teaching materials, provided that suitable acknowledgement of OECD as source and copyright owner is given. All requests for commercial use and translation rights should be submitted to rights@oecd.org. 


\title{
The Productivity-Wage Premium: Does Size still Matter in a Service Economy?
}

\author{
Giuseppe Berlingieri $^{1,2,3}$, Sara Calligaris ${ }^{1}$ and Chiara Criscuolo ${ }^{1,3} *$ \\ ${ }^{1} \mathrm{OECD}$ \\ ${ }^{2}$ ESSEC Business School \\ ${ }^{3}$ Centre for Economic Performance (LSE)
}

\begin{abstract}
Ever since Moore (1911) a large empirical and theoretical literature has established the existence of a firm size-wage premium. At the same time, a second regularity in empirical work, linking size and productivity, has inspired a vast literature in multiple fields. However, the majority of the existing evidence is based on manufacturing data only. With manufacturing nowadays accounting for a very small share of the economy in many countries, whether productivity, size, and wages are closely linked, and how tight this link is across sectors, is still an open question. Using a unique dataset that collects micro-aggregated firm-level information on productivity, size, and wages for the entire economy in 17 countries over the 1994-2012 period, this paper unveils a much more subtle picture. First, while in the manufacturing sector both productivity and wages increase monotonically with firm size, the same is not true in the service sector. Second, a tight and positive link between wages and productivity is instead found in both manufacturing and services. The combination of these results suggests that, when looking at data for a much larger share of the economy, the "size-wage premium" becomes more a "productivity-wage premium". Unbundling the relationship between size, wages, and productivity has first-order policy implications for both workers and firms.
\end{abstract}

Keywords: Productivity, Size-Premium, Wages.

JEL codes: E2; D2; J3

${ }^{*}$ Giuseppe Berlingieri, giuseppe.berlingieri@oecd.org; Sara Calligaris, sara.calligaris@oecd.org; Chiara Criscuolo, chiara.criscuolo@oecd.org. 


\section{Contents}

1 Introduction $\quad 5$

2 Data 8

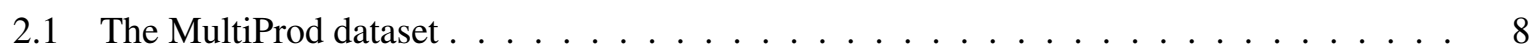

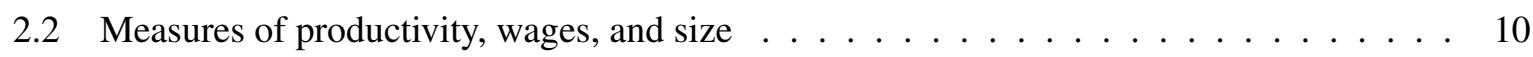

3 The size-wage and size-productivity premia $\quad 11$

3.1 Empirical strategy and main results . . . . . . . . . . . . . . . . 11

3.2 Robustness . . . . . . . . . . . . . . . . . . . . . . . 14

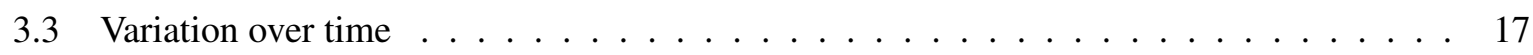

4 The productivity-wage premium $\quad 20$

5 Conclusions and next steps 23

$\begin{array}{lll}\text { A Additional results } & 30\end{array}$

\section{List of Figures}

1 Averages by size classes and productivity quantiles . . . . . . . . . . . . . . . . 6

2 Wages and productivity by size classes within countries, sectors and years . . . . . . . . . . 12

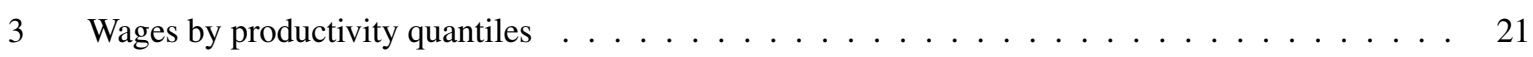

A.4 Wages by gross output quantiles . . . . . . . . . . . . . . . . . . . 33

\section{List of Tables}

1 Years covered in the MultiProd dataset . . . . . . . . . . . . . . . . . . 9

2 Firm and employment distribution by size classes . . . . . . . . . . . . . . . . . . 9

3 Wages and productivity by size classes . . . . . . . . . . . . . . . . . . . . . . . . 14

4 Robustness of wages by size classes . . . . . . . . . . . . . . . . . . . . 15

5 Robustness of labour productivity by size classes _ . . . . . . . . . . . . . . . . 16

6 Robustness of multi-factor productivity by size classes . . . . . . . . . . . . . . . . 17

7 The size premium over time . . . . . . . . . . . . . . . . . . . 18

8 Wages by productivity quantiles . . . . . . . . . . . . . . . . . . . 22

A.1 Wages and productivity by size classes, manufacturing vs. services . . . . . . . . . . . . 30

A.2 Baseline and robustness of wages by size classes _ . . . . . . . . . . . . . . . 30

A.3 Baseline and robustness of labour productivity by size classes . . . . . . . . . . . . . . 31

A.4 Baseline and robustness of multi-factor productivity by size classes . . . . . . . . . . . 31

A.5 Coefficient for large $(250+)$ service firms by 2-digit sector . . . . . . . . . . . . . . . 32

A.6 Wages by productivity quantiles, manufacturing vs. services . . . . . . . . . . . . . . 32

A.7 Wages by gross output quantiles . . . . . . . . . . . . . . . . . . . . 33

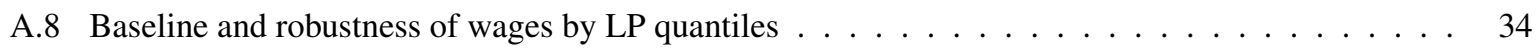

A.9 Baseline and robustness of wages by MFP quantiles . . . . . . . . . . . . . . . . . . . . 34 


\section{Introduction}

The 20th century has been characterised by Fordism and large conglomerates, an era in which the traditional paradigm would consider large firms as the most productive and paying the highest wages. In this context, it should come at no surprise that the link between firm productivity, firm size, and the wages paid to workers has been the subject of many economic studies, both from a theoretical and empirical point of view. Several theoretical models indeed predict a tight positive relationship between productivity and size, as well as wages and size. In this paper we show that, even though this is still true for the small part of the economy still represented by manufacturing, in the much larger service sector of today's world the link of productivity and wages with size loses much of its significance. The new "top players", i.e. those who are the most productive and pay the highest wages, are often only hiring a handful of workers (Autor et al., 2017a; Kehrig and Vincent, 2017). The strong link between size, productivity and wages is broken, or at least in the way it has been traditionally established.

The fact that larger businesses pay higher wages has long been considered a stylised fact in the literature. This relationship, called the "size-wage premium", was discovered by Moore (1911) and then confirmed not only for the US (Brown and J. Medoff, 1989; Bayard and K. R. Troske, 1999; K. Troske, 1999; Oi and Idson, 1999; Barth et al., 2018), but also for other industrialised countries (see Morissette, 1993, for Canada, Main and Reilly, 1993, for Great Britain, Albaek et al., 1998, for the Scandinavian countries, and Schmidt and Zimmermann, 1991, for Germany).

Both the theoretical and empirical literature have suggested that this positive size premium may, at least partly, reflect productivity differentials amongst firms of different sizes. Significant heterogeneity in productivity exists among firms (Syverson, 2011), and theories of the firms predict that this heterogeneity in productivity will translate in size differentials, with more productive firms being also larger (Lucas, 1978; Melitz, 2003). These models imply that each producer has a unique optimal size that is increasing with its productivity level. A multitude of empirical studies have been inspired by these theories, confirming empirically the positive correlation between productivity and size (see, for example, Bartelsman et al., 2013, who document a positive covariance between productivity and size for Germany, Hungary, Netherlands, Romania, Slovenia, the United Kingdom, and the US, and Van Ark and Monnikhof, 1996, who document the relationship between labour productivity and size for France, Germany, Japan, the United Kingdom and the US).

At the same time, models of on-the-job-search predict that high productivity firms will be larger and pay higher wages (Burdett and Mortensen, 1998; Moscarini and Postel-Vinay, 2009; Moscarini and Postel-Vinay, 2013; Moscarini and Postel-Vinay, 2016). These models generally make a natural assumption about job-to-job moves in the labour market: employers offering higher wages induce workers to leave lower paying jobs and accept their employment offers. A related prediction of these models is that, since larger businesses offer higher wages, voluntary job moves should generally reallocate workers from smaller to larger employers.

Moreover, models of imperfect competition in the labour market (e.g. see Manning, 2011; Card et al., 2018) predict that firm heterogeneity in productivity will affect the distribution of firm size and of firm-specific wage premia, as well as the degree of sorting of different skill groups across firms. Similarly, the empirical literature on rent sharing also provides evidence of a significant relationship between wages and firms productivity. Existing empirical evidence indeed points to a close link between dispersion in productivity and dispersion in wages, as well as their evolution over time (Berlingieri et al., 2017b).

However, the vast majority of these studies focus exclusively on manufacturing sectors; often because of lack of data, services are rarely analysed in this literature, especially in a cross-country dimension. With manufacturing representing only around $15 \%$ of total value added and employment in OECD economies (with 
a decreasing trend over time), it is therefore important to understand whether the stylised fact that size is strongly correlated with both wages and productivity can be extended at face value to the service sector, or whether there are significant differences between the two sectors.

This paper is aimed at answering these questions using a novel data source, the OECD MultiProd dataset, which is based on the full population of firms, or a representative re-weighted sample, in most sectors of the economy. MultiProd collects micro-aggregated firm-level data on productivity, size, and wages for the entire economy in more than 20 countries over the period 1994-2012. In this paper we focus exclusively on 17 countries for which information on firm size is available, and for both manufacturing and non-financial market services.

Figure 1 illustrates the main message of this paper. By simply plotting the (weighted) cross-country average of wages and labour productivity by eight size classes for manufacturing and market services separately, the figure shows that in manufacturing productivity and wages increase significantly with firm size, but that this relationship does not hold for services. Both labour productivity and wages exhibit a distribution over size classes that is flatter in services than in manufacturing. On the contrary, if we plot the (weighted) cross-country average of wages by five bins of the productivity distribution, wages increase with firm productivity in both sectors.

\section{Figure 1. Averages by size classes and productivity quantiles}

(a) Wages by size classes

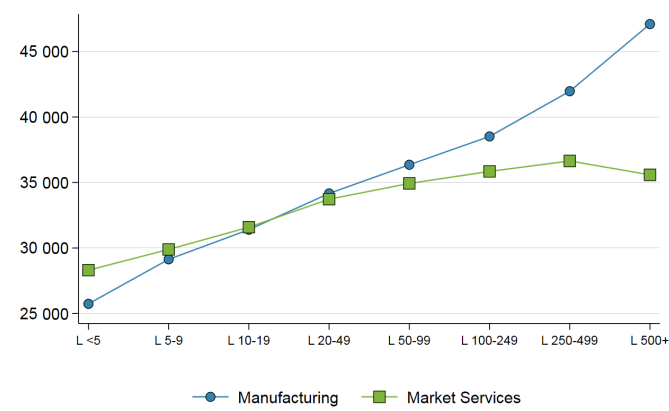

(c) Wages by labour productivity quantiles

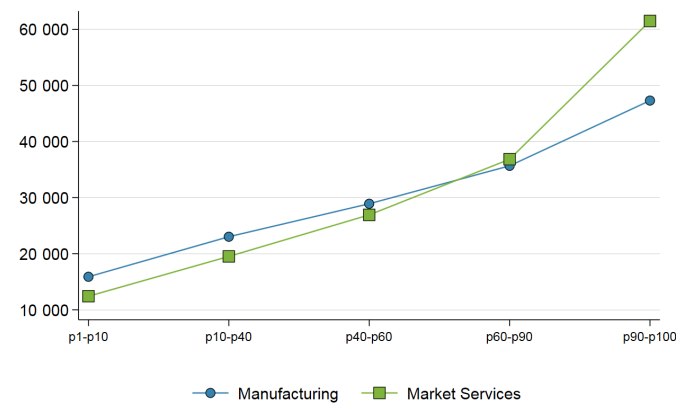

(b) Labour productivity by size classes

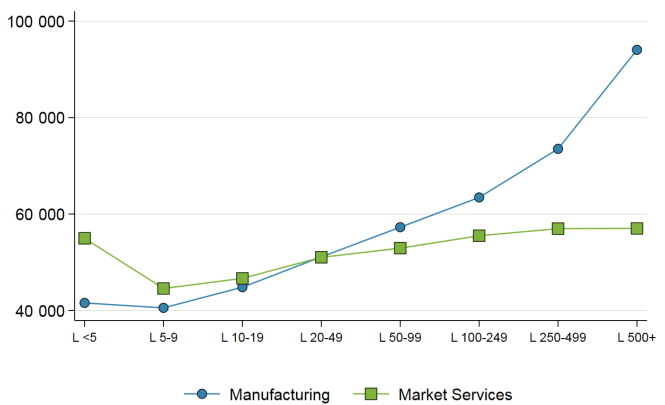

(d) Wages by multi-factor productivity quantiles

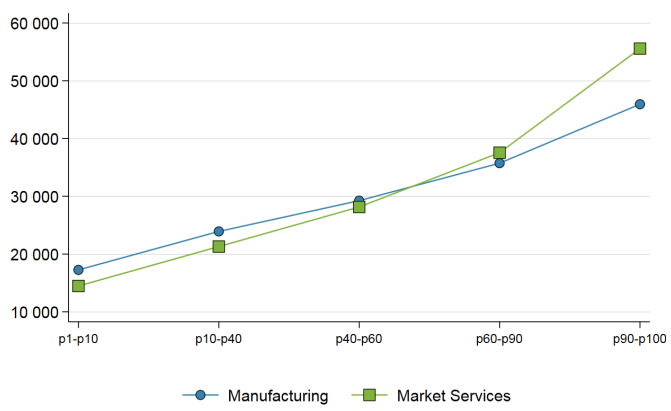

Note: Countries included: AUS, AUT, BEL, CAN, CHE, CHL, DEU, DNK, FIN, FRA, HUN, ITA, JPN, NLD, NOR, PRT, SWE. Figures $1 \mathrm{a}$ and $1 \mathrm{~b}$ are weighted averages over 8 size classes: very micro (less than 5 employees), micro (5-9), small (10-19), medium-small (20-49), medium-large (100-249), large (250-499), very large (more than 500). Figures 1c and 1d are weighted averages over 5 bins of the productivity distribution: $1^{\text {st }}$ to $10^{\text {th }}$ percentile, $10^{\text {th }}$ to $40^{\text {th }}, 40^{\text {th }}$ to $60^{\text {th }}, 60^{\text {th }}$ to $90^{\text {th }}$, and $90^{\text {th }}$ to $100^{\text {th }}$.

To further investigate the link of productivity (measured both as labour productivity - LP - and multi-factor productivity - MFP) and wages with size, we adopt an econometric strategy that focuses on these links within countries, disaggregated (2-digit) sectors, and years. This strategy ensures that the relationship of wages and 
productivity with size at the macro-level is not driven by compositional effects of more disaggregated sectors or by aggregate time trends. In the most demanding specification we control for any unobservable characteristic that varies at the country-industry-year level. We find that, in line with the existing literature, both productivity and wages increase monotonically with firms' size in the manufacturing sector. Conversely, the distribution is much flatter in the non-financial market service sector, where firms above 20 employees pay on average rather similar wages to their workers, and exhibit very similar productivity levels (both LP and MFP). While on average small service firms pay higher wages and are more productive than their counterparts in the manufacturing sector, the opposite is true for large firms. This result is in line with Haltiwanger et al. (2015), which show that voluntary movements of workers across jobs generally reallocate workers from lower paying to higher-paying firms, but not from smaller to larger firms.

Given that the positive size-wage premium may, at least partly, reflect productivity differentials amongst firms of different sizes, we turn to investigating the direct link between wages and productivity. We ask ourselves whether wages respond more to firms' productivity compared to size, and whether the relationship is similar across sectors. We do find that wages increase with productivity, and the relationship is very tight in manufacturing and even moreso in services. The combination of these results suggests that size does not "mediate" the relationship between productivity and wages in the service sector. When looking at data going beyond manufacturing, the "size-wage premium" becomes rather a "productivity-wage premium".

Unbundling the relationship between size, wages, and productivity has first-order policy implications for both workers and firms. Our results show that the size dimension is much less important in the service sector, where there might be SMEs with very high levels of productivity that pay very high wages. These findings call for a reconsideration of industrial policy design, which could be summarised along the following three main lines:

- In today's service economy, size contingent policies should be based on sales, or even better sales or value added per employee. Designing policy measures based on employment size with the rationale that the number of employees proxies for wages and productivity might have unintended consequences in the service sector, and might exclude those firms that actually need them the most (e.g. support for training or organisational innovation in large but poorly performing firms).

- Policies that focus on raising productivity might be a more direct way to increase both growth and wages, so the focus should be on measures that raise investment in intangibles, skills etc.

- The traditional paradigm in a manufacturing economy implied that the most productive firms were also the largest and therefore shared the benefits of their high productivity with a very large number of workers, while this is not the case in today's service economy. Policy makers should therefore be concerned that the most productive firms might actually be relatively small (and smaller than before), which might increase concerns regarding the inclusivity of the growth model of the new service economy.

Previous research has shown that there are large and growing productivity gaps between the most and the least productive firms, even within sectors (Andrews et al., 2016; Berlingieri et al., 2017b). This paper adds to this debate by showing that the most productive firms at the top might not be the largest ones, which increases the likelihood of productivity gains being shared only with the few workers that are employed there. Policy makers might need to reflect on the potential implications that these trends have for perceived and measured inequality.

The rest of the paper is organised as follow: Section 2 describes the data sources and the measures used for the analysis; in Section 3 we analyse the link between wages and size as well as productivity and size across 17 countries from the mid-1990 to the recent post-recession period, i.e. up to 2012; in Section 4 we investigate the link between wages and productivity for the same sample; Section 5 concludes. 


\section{Data}

This section provides an overview of the data used, as well as the main measures of productivity, wages and size used in this work. Further detailed information on the MultiProd project and the methodology adopted can be found in Berlingieri et al. (2017a) .

\subsection{The MultiProd dataset}

The analysis conducted in this report relies on the work undertaken in the last few years within the OECD "MultiProd" project. The implementation of the MultiProd project is based on a standardised STATA ${ }^{\circledR}$ routine that micro-aggregates micro-data from production surveys and business registers, via a distributed microdata analysis. This methodology was pioneered in the early 2000s in a series of cross-country projects on firm demographics and productivity (Bartelsman et al., 2005; Bartelsman et al., 2009). The OECD currently follows this approach in three ongoing projects: MultiProd, DynEmp, and MicroBeRD. ${ }^{1}$ The distributed micro-data analysis involves running a common code in a decentralised manner by representatives in national statistical agencies or experts in public institutions, who have access to the national micro-level data. At this stage, micro-aggregated data are generated by the centrally designed, but locally executed, program codes, which are then sent back for comparative cross-country analysis to the OECD.

The advantages of this novel data collection methodology are manifold: it puts a lower burden on national statistical agencies and limits running costs for such endeavours. Importantly, it also overcomes the confidentiality constraints of directly using national micro-level statistical database, while at the same time achieving a high degree of harmonisation and comparability across countries, sectors, and over time.

The MultiProd program relies on two main data sources in each country. First, administrative data or production surveys (PS), which contain all the variables needed for the analysis of productivity but may be limited to a sample of firms. Second, a business register (BR), which contains a more limited set of variables but for the entire population of firms. The program works also in the absence of a business register, which is not needed when administrative data on the full population of firms are available. However, when data come from a PS, its availability substantially improves the representativeness of results and, thus, their comparability across countries. ${ }^{2}$

Census and administrative data, indeed, normally cover the whole population of businesses with at least one employee. Still, these datasets do not always exist and PS data need to be used. One of the big challenges of working with firm-level production surveys is that the selected sample of firms might yield a partial and biased picture of the economy. Whenever available, BRs, which typically contain the whole population of firms, are therefore used in MultiProd to compute a population structure by year-sector-size classes. This structure is then used to re-weight data contained in the PS in order to construct data that are as representative as possible of the whole population of firms and comparable across countries.

At the time of writing, 24 countries have been successfully included in the MultiProd database (namely, Australia, Austria, Belgium, Brazil, Canada, Chile, the People's Republic of China, Costa Rica, Denmark, Finland, France, Germany, Hungary, Indonesia, Italy, Japan, Luxembourg, Netherlands, Norway, New Zealand, Portugal, Sweden, Switzerland, and Viet Nam). For most countries the time period spans from early 2000s to 2012. For Chile, Austria and Switzerland the time horizon is shorter (starting in 2005, 2008 and 2009 respectively), whereas for Finland, France, Japan and Norway data are available at least since 1995. 
MultiProd collects data for all sectors of the entire economy, whenever available. However, for the purposes of this analysis we have restricted our sample to manufacturing and non-financial market services. ${ }^{3}$ In addition, given the nature of the analysis, and in order to guarantee the comparability across macro-sectors, we restrict our sample to those countries providing wages and productivity statistics by size classes and productivity quantiles for both manufacturing and non-financial market services. The final sample includes 17 countries (namely, Australia, Austria, Belgium, Canada, Chile, Denmark, Finland, France, Germany, Hungary, Italy, Japan, Netherlands, Norway, Portugal, Sweden, and Switzerland). Table 1 details the years covered for each country.

Table 1. Years covered in the MultiProd dataset

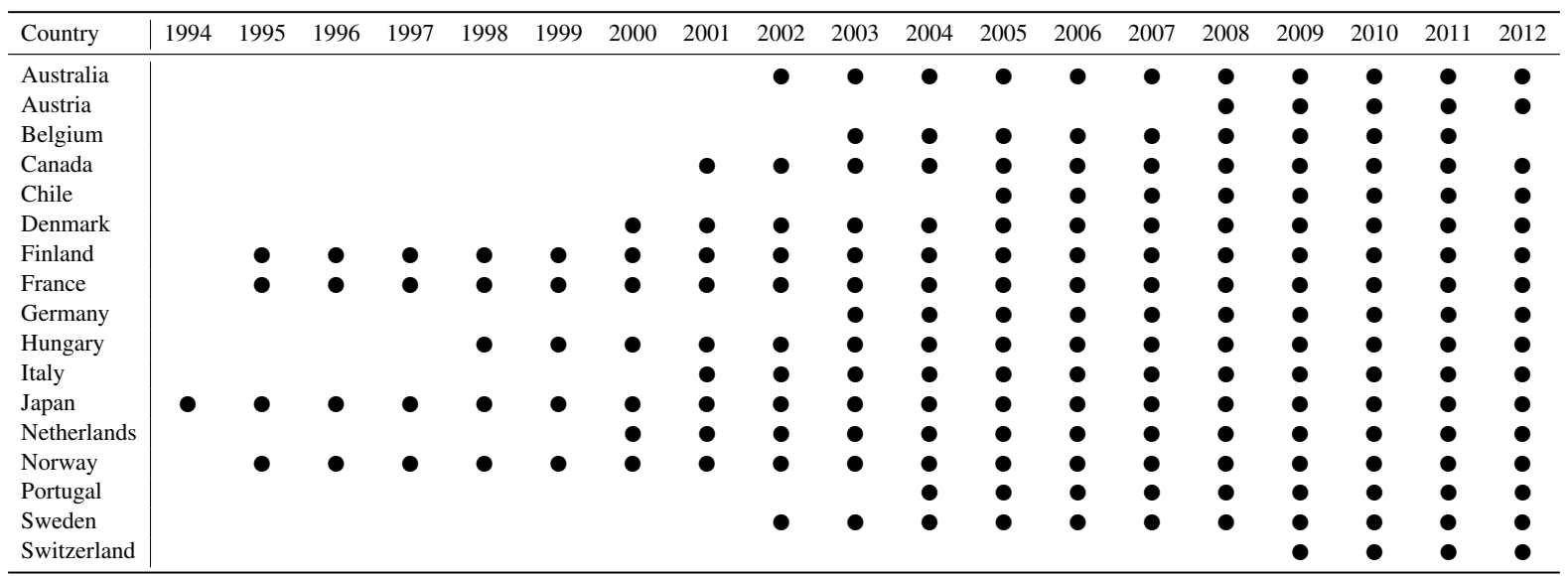

Table 2 shows the yearly average number of firms and employees by size classes: micro (1-9 employees), small (10-19 employees), medium-small (20-49 employees), medium (50-249 employees), large (at least 250 employees). The average number of firms decreases with the size class: in the manufacturing (services) sector micro firms are $58 \%(82 \%)$ of the sample, whereas the large ones represent less than $3 \%$ of firms $(1 \%)$. On the contrary, employment is more concentrated in firms with more than 50 employees $(81 \%$ in manufacturing, $69 \%$ in services); however, overall in services the distribution is more homogeneous among classes. Stated differently, in our sample on average SMEs, i.e., firms with less than 250 employees, represent 97\% (99\%) of firms in the manufacturing (services) sector and $45 \%(50 \%)$ of employment.

Table 2. Firm and employment distribution by size classes

\begin{tabular}{lccccc}
\hline & \multicolumn{2}{c}{ Manufacturing } & & \multicolumn{2}{c}{ Services } \\
\cline { 2 - 3 } \cline { 5 - 6 } Size Class & Firms & Employees & & Firms & Employees \\
\hline Micro (1-9) & $58 \%$ & $5 \%$ & & $82 \%$ & $14 \%$ \\
Small (10-19) & $14 \%$ & $5 \%$ & & $9 \%$ & $7 \%$ \\
MediumSmall (20-49) & $14 \%$ & $10 \%$ & & $5 \%$ & $10 \%$ \\
Medium (50-249) & $11 \%$ & $26 \%$ & & $3 \%$ & $19 \%$ \\
Large (250+) & $3 \%$ & $55 \%$ & & $1 \%$ & $50 \%$ \\
\hline
\end{tabular}

Note: Manufacturing and services only. Numbers are averages across countries and years. Countries included: AUS, AUT, BEL, CAN, CHE, CHL, DEU, DNK, FIN, FRA, HUN, ITA, JPN, NLD, NOR, PRT, SWE. 


\subsection{Measures of productivity, wages, and size}

The analysis relies on two measures of productivity. The first, labour productivity, is the most widely used in the literature and aims at capturing the amount of output produced by a firm for a given amount of labour input. It is computed at the firm level as the (real) value-added per worker:

$$
\mathrm{LP}_{-} \mathrm{VA}_{i t}=\frac{V A_{i t}}{L_{i t}}
$$

where $V A_{i t}$ is the value-added of firm $i$ at time $t$, and $L_{i t}$ is its employment. ${ }^{4}$ The advantage of this measure is that it is widely available, and fairly immune to measurement error. Moreover, it can be easily aggregated into sector-level or country-level labour productivity using employment weights.

One of the main drawbacks of labour productivity is that it does not quantify the impact of other inputs, such as capital, while for some policy questions it might be important to disentangle whether labour productivity gains are actually driven by an increase in physical capital. In order to do this, the MultiProd data contain various measures of multi-factor productivity, which is a productivity measure that accounts not only for labour but also for capital inputs. 5

The measure of MFP used in this report is estimated econometrically at the firm-level using the Wooldridge (2009) control function approach with value added as a measure of output. Firms are assumed to have a Cobb-Douglas production function, but not necessarily constant returns to scale:

$$
Y_{i t}=A_{i t} K_{i t}^{\beta_{K}} L_{i t}^{\beta_{L}},
$$

where $A_{i t}$, firm $i$ 's MFP at time $t$, is typically unobserved and has to be estimated.

The Wooldridge (2009) procedure relies on estimating variable inputs with a polynomial of lagged inputs and a polynomial of intermediates. It allows for the identification of the variable input and yields consistent standard errors. ${ }^{6}$

The measure of wages contained in the dataset is computed as a firm's total labour costs divided by the number of employees, corresponding therefore to the average wage at the firm level. In fact, wages at the worker-level, as well as other worker characteristics are not observed in the source data. This implies that within-firm wage dispersion or its contribution to overall wage dispersion cannot be estimated. ${ }^{7}$

The dataset has been split into five size classes and five bins of the productivity (both LP and MFP) distribution. The size classes are: micro (1-9 employees), small (10-19), medium-small (20-49), medium (50-249) and large (more than 250). The bins of the productivity distribution are: $1^{\text {st }}$ to $10^{\text {th }}$ percentile, $10^{\text {th }}$ to $40^{\text {th }}, 40^{\text {th }}$ to $60^{\text {th }}, 60^{\text {th }}$ to $90^{\text {th }}$, and $90^{\text {th }}$ to $100^{\text {th }}$. The number of size classes and productivity bins has been limited to avoid too few observations in a cell (which is detailed at the country, 2-digit, year, and size class or productivity bin level) and, thus, to overcome confidentiality issues. 


\section{The size-wage and size-productivity premia}

In this section we analyse the link of wages and productivity with size. In particular, in Section 3.1 we describe the empirical strategy used, and our main results on the size-wage and size-productivity premia. In Section 3.2 we investigate the robustness of our findings to a series of potentially omitted variables. Finally, in Section 3.3 we test whether there is a change in the size premium in recent years.

\subsection{Empirical strategy and main results}

To analyse the link of wages and productivity with size, we investigate the relationship within countries, disaggregated (2-digit) sectors, and years. More precisely, to establish whether there is a systematic and significant difference in size premia between manufacturing and services, we focus on the relative differentials between the two sectors estimating the following equation:

$$
y_{c j s t}=\mathbf{D}_{c j s t}^{\prime} \beta+\boldsymbol{z}_{c j}+\boldsymbol{\tau}_{t}+\boldsymbol{\varepsilon}_{c j s t},
$$

where $y_{c j s t}$ is the average $y$ in country $c$, 2-digit sector $j$, size class $s$, and year $t$. The left hand side $y$ stands for log-wages, log-LP and log-MFP, depending on the regression performed. ${ }^{8}$ Moreover, $\mathbf{D}$ is a vector of categorical variables for each size class. Therefore, the estimates of elements of $\beta$ capture the average size-wage and size-productivity differential for a given size class with respect to micro firms. In all regressions we control for a battery of country-sector fixed effects $z_{c j}$, and year fixed effects $\tau_{t}$. In particular, $z_{c j}$ control for the specific levels of $y$ in each country and sector, and $\tau_{t}$ control for the specific levels of $y$ in each year, so that the estimates of elements of $\beta$ capture a more accurate measure of wages and productivity within each size class, already cleaned by country-sector specificities and temporal trends.

Figure 2 shows the results of these regressions, considering separately manufacturing and non-financial market services. ${ }^{9}$ The baseline category is micro firms (1-9 employees), so the bars display the wage and productivity premia with respect to that category. The results show that while in the manufacturing sector wages are on average significantly increasing with size classes, this does not hold in the service sector. Average wages in large service firms are indeed essentially the same as those paid by medium firms. The results capture the average effect of size in the macro-sector once controlling for 2-digit sector by country as well as year fixed effects. The advantage of controlling for unobservable time invariant characteristics at the 2 digit sectoral level comes at the cost of a loss in precision in the definition of size classes; in fact, the MultiProd database contains results at the 2-digit level only for 5 size classes. We are therefore not able to unveil the more subtle size profiles that appeared in the raw data for the aggregate macro-sector displayed in Figure 1, where eight size classes were available. In particular, at the 2-digit level, we cannot provide a full spectrum of large firms, which are all lumped together into a single size class.

Interestingly, we find a similar result for productivity; while in the manufacturing sector there is a monotonic increase of average productivity with size, this result is much milder in the service sector. Considering LP (Figure 2b), we find the hump-shaped pattern between productivity and size already seen for wages. Firms with more than 250 employees are on average less productive than smaller firms. In terms of MFP (Figure 2c), we find much more similar productivity levels among size classes in services than in manufacturing and, even if MFP increases with size also in services, the estimated size-productivity premium is substantially smaller than in manufacturing. 
Figure 2. Wages and productivity by size classes within countries, sectors and years

(a) Wages

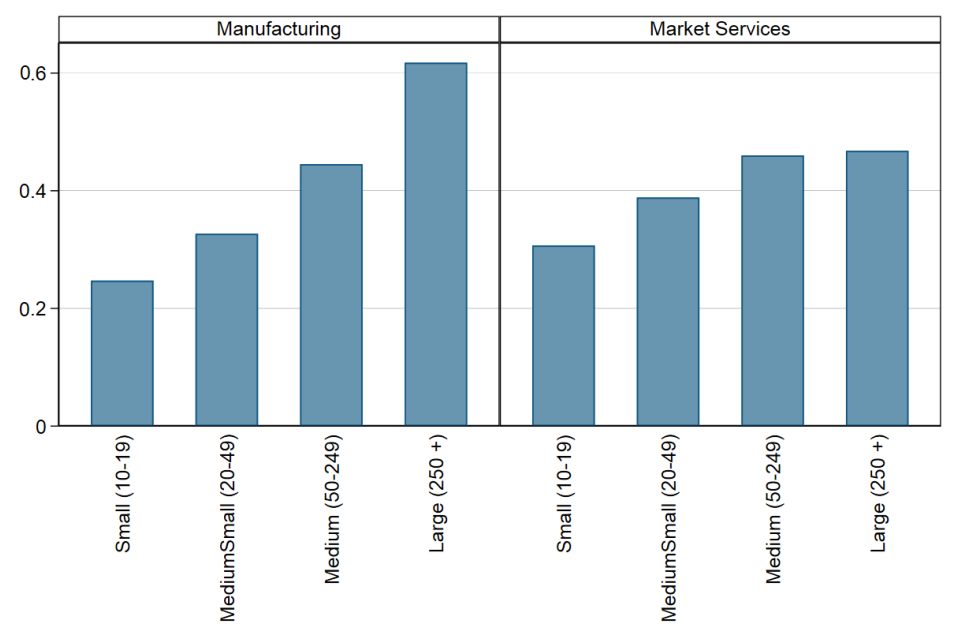

(b) Labour productivity

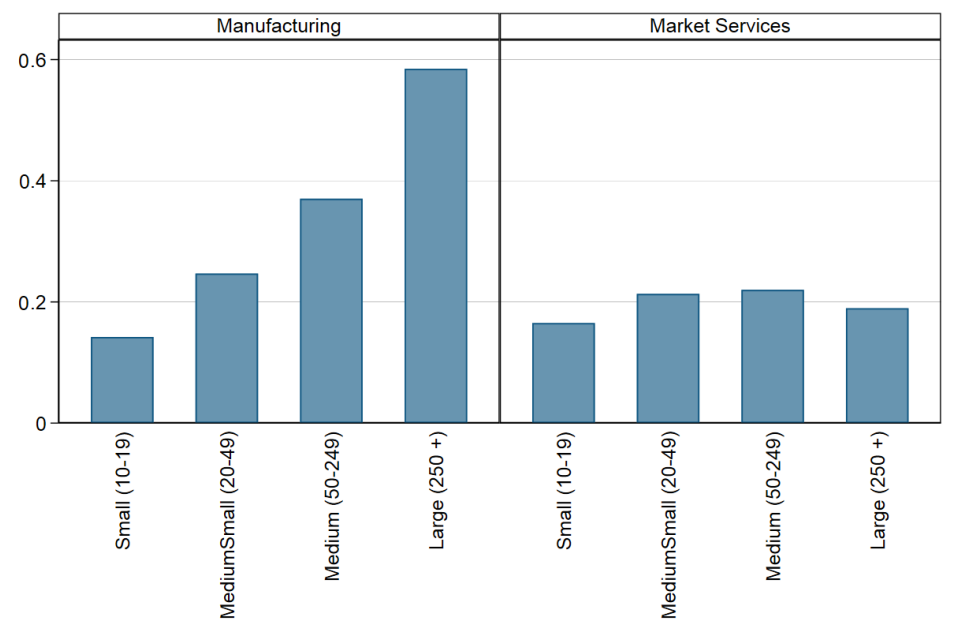

(c) Multi-factor productivity

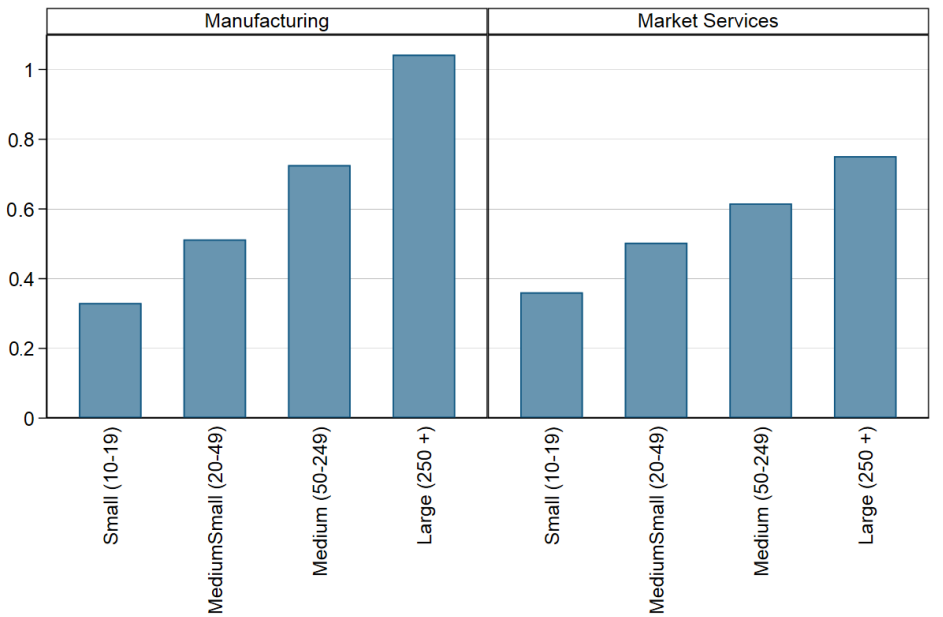

Note: The figure plots the estimated size class dummies $\boldsymbol{\beta}_{s}$ of a regression of, respectively, log-wages, $\log$-LP, and log-MFP within country-sector pairs and years, as estimated in Equation (3). Data used include the following countries: AUS, AUT, BEL, CAN, CHE, CHL, DEU,DNK, FIN, FRA, HUN, ITA, JPN, NLD, NOR, PRT, SWE. 
To establish whether there is a systematic and significant difference in size premia between manufacturing and services, we perform a similar exercise but specifically looking at the differential impact of services compared to manufacturing. In particular, we focus on the relative premia between manufacturing and services through the following regressions:

$$
\begin{gathered}
y_{c j s t}=\mathbf{D}_{c j s t}^{\prime} \beta+m_{c j s t} \mathbf{D}_{c j s t}^{\prime} \gamma+\boldsymbol{z}_{c j}+\boldsymbol{\tau}_{t}+\boldsymbol{\varepsilon}_{c j s t}, \quad \text { and } \\
y_{c j s t}=\mathbf{D}_{c j s t}^{\prime} \beta+m_{c j s t} \mathbf{D}_{c j s t}^{\prime} \boldsymbol{\gamma}+\boldsymbol{\theta}_{c j t}+\varepsilon_{c j s t},
\end{gathered}
$$

where $m_{c j s t}$ is a macro-sector indicator variable that takes value 0 for manufacturing and 1 for non-financial market services. In this case the estimates of elements of $\beta$ capture the average size-wage and size-productivity differentials for a given size class with respect to micro firms in manufacturing, whereas estimates of elements of $\gamma$ capture the differential size-premium deriving from being a service firm with respect to manufacturing in each size class. In other words, an estimate of 0 for an element of $\gamma$ would suggest that for that particular size class there is no additional premium/loss from being in services, i.e., that the size differentials for being in class size $s$ is on average the same in manufacturing and services. As before, in Equation (4) we control for specific country-sector $\left(z_{c j}\right)$ and year fixed effects $\left(\tau_{t}\right)$; in Equation (5), instead, we control for country-sector-year fixed effects $\left(\theta_{j c t}\right)$, to check the robustness of our results for any possible shock affecting a sector $s$ in country $c$ in a specific year $t$. Essentially in the second specification we control for any unobservable characteristic that varies at the country-sector-year level, as any industry level control variable would do.

Results of these regressions are shown in Table 3. Columns 1-3 refer to Equation (4), Columns 4-6 refer to Equation (5). First of all, the results confirm that the correlation of wages and productivity with size is strongly significant in manufacturing (the first four non-interacted coefficients). Moreover, the size premium appears to be stronger for MFP than LP, and both fixed effects specifications present very similar results, showing that standard industry level variables do not affect this link.

Looking at the size-wage differential in services, the last four coefficients in Columns 1 and 4 show that firms with less than 50 employees in the service sector pay on average higher wages compared to manufacturing firms in the same size classes. However, this "service premium" disappears for firms with 50-249 employees, and becomes even negative for large firms. Overall these results suggest that the positive correlation between wages and size is lower in services than in manufacturing, and that the distribution of wages across size classes is flatter in services. Looking at the correlation between productivity and size, we find similar results. For LP, we do not find a significantly positive "service premium" for small firms, whereas for all other size classes service firms display a significantly lower productivity compared to equally sized firms in manufacturing. Furthermore, the negative interaction coefficient increases in absolute value with the size class, indicating that the difference between manufacturing and services increases with size and that the productivity-size premium is much weaker, if not absent, in service firms above 20 employees. For what concerns MFP, we find a similar picture: while we find a small "service premium" for the small size class, medium and large firms in the service sector display significantly lower productivity levels compared to equally sized manufacturing firms. Again, the negative interaction coefficient increases significantly over the size classes, weakening the correlation between productivity and size. Since the MFP-size premium appears to be very strong in the manufacturing sector, the negative interaction effects do not go all the way to reversing the size premium in the service sector as for LP; however, the overall size premium is considerably reduced, especially for firms above 50 employees. 
Table 3. Wages and productivity by size classes

\begin{tabular}{|c|c|c|c|c|c|c|}
\hline & $\begin{array}{c}(1) \\
\ln (W)\end{array}$ & $\begin{array}{c}(2) \\
\ln (\mathrm{LP})\end{array}$ & $\begin{array}{c}(3) \\
\ln \left(\mathrm{MFP}_{-} \mathrm{W}\right)\end{array}$ & $\begin{array}{c}(4) \\
\ln (W)\end{array}$ & $\begin{array}{c}(5) \\
\ln (\mathrm{LP})\end{array}$ & $\begin{array}{c}(6) \\
\ln \left(\mathrm{MFP}_{-} \mathrm{W}\right)\end{array}$ \\
\hline Small (10-19) & $\begin{array}{c}0.247^{* * *} \\
(0.010)\end{array}$ & $\begin{array}{c}0.143^{* * *} \\
(0.008)\end{array}$ & $\begin{array}{c}0.331^{* * *} \\
(0.008)\end{array}$ & $\begin{array}{c}0.247^{* * *} \\
(0.010)\end{array}$ & $\begin{array}{c}0.142^{* * *} \\
(0.007)\end{array}$ & $\begin{array}{c}0.329^{* * *} \\
(0.008)\end{array}$ \\
\hline MediumSmall (20-49) & $\begin{array}{c}0.327^{* * *} \\
(0.011)\end{array}$ & $\begin{array}{c}0.245^{* * *} \\
(0.009)\end{array}$ & $\begin{array}{c}0.511^{* * *} \\
(0.013)\end{array}$ & $\begin{array}{c}0.326^{* * *} \\
(0.011)\end{array}$ & $\begin{array}{c}0.246^{* * *} \\
(0.009)\end{array}$ & $\begin{array}{c}0.511^{* * *} \\
(0.013)\end{array}$ \\
\hline Medium (50-249) & $\begin{array}{c}0.445^{* * *} \\
(0.013)\end{array}$ & $\begin{array}{c}0.369^{* * *} \\
(0.010)\end{array}$ & $\begin{array}{c}0.725^{* * *} \\
(0.018)\end{array}$ & $\begin{array}{c}0.445^{* * *} \\
(0.013)\end{array}$ & $\begin{array}{c}0.368^{* * *} \\
(0.010)\end{array}$ & $\begin{array}{c}0.723^{* * *} \\
(0.017)\end{array}$ \\
\hline Large $(250+)$ & $\begin{array}{c}0.618^{* * *} \\
(0.014)\end{array}$ & $\begin{array}{c}0.584^{* * *} \\
(0.010)\end{array}$ & $\begin{array}{c}1.042^{* * *} \\
(0.024)\end{array}$ & $\begin{array}{c}0.618^{* * *} \\
(0.014)\end{array}$ & $\begin{array}{c}0.584^{* * *} \\
(0.010)\end{array}$ & $\begin{array}{c}1.040^{* * *} \\
(0.024)\end{array}$ \\
\hline Small $(10-19) \times$ Market Services & $\begin{array}{c}0.060^{* * *} \\
(0.022)\end{array}$ & $\begin{array}{c}0.022 \\
(0.014)\end{array}$ & $\begin{array}{l}0.029^{*} \\
(0.016)\end{array}$ & $\begin{array}{c}0.059^{* * *} \\
(0.022)\end{array}$ & $\begin{array}{c}0.022 \\
(0.014)\end{array}$ & $\begin{array}{l}0.030^{*} \\
(0.016)\end{array}$ \\
\hline MediumSmall (20-49) $\times$ Market Services & $\begin{array}{l}0.062^{* *} \\
(0.026)\end{array}$ & $\begin{array}{l}-0.032^{*} \\
(0.016)\end{array}$ & $\begin{array}{l}-0.008 \\
(0.025)\end{array}$ & $\begin{array}{l}0.061^{* *} \\
(0.026)\end{array}$ & $\begin{array}{c}-0.035^{* *} \\
(0.016)\end{array}$ & $\begin{array}{l}-0.010 \\
(0.025)\end{array}$ \\
\hline Medium (50-249) $\times$ Market Services & $\begin{array}{c}0.015 \\
(0.032)\end{array}$ & $\begin{array}{c}-0.150^{* * *} \\
(0.020)\end{array}$ & $\begin{array}{c}-0.110^{* * *} \\
(0.041)\end{array}$ & $\begin{array}{c}0.014 \\
(0.031)\end{array}$ & $\begin{array}{c}-0.152^{* * *} \\
(0.020)\end{array}$ & $\begin{array}{c}-0.111^{* * *} \\
(0.040)\end{array}$ \\
\hline Large $(250+) \times$ Market Services & $\begin{array}{c}-0.150^{* * *} \\
(0.034)\end{array}$ & $\begin{array}{c}-0.395^{* * *} \\
(0.025)\end{array}$ & $\begin{array}{c}-0.291^{* * *} \\
(0.065)\end{array}$ & $\begin{array}{c}-0.151^{* * *} \\
(0.034)\end{array}$ & $\begin{array}{c}-0.395^{* * *} \\
(0.025)\end{array}$ & $\begin{array}{c}-0.290^{* * *} \\
(0.065)\end{array}$ \\
\hline Observations & 20297 & 20105 & 18769 & 20278 & 20085 & 18749 \\
\hline Adj. R-Square & 0.968 & 0.954 & 0.989 & 0.963 & 0.964 & 0.988 \\
\hline Country-sector Year FE & YES & YES & YES & & & \\
\hline Country-sector-year FE & & & & YES & YES & YES \\
\hline Num. Countries & 17 & 17 & 17 & 17 & 17 & 17 \\
\hline
\end{tabular}

\subsection{Robustness}

In this section we investigate the robustness of our findings to a series of potentially omitted variables that might be correlated with size and, at the same time, affect wages and productivity. Columns 4-6 of Table 3 control for country-industry-year fixed effects, which capture any unobservable country-industry characteristics that can also vary over time. This specification already rules out the possibility that any of the typical industry level variables might affect the results. What is left is any variable that varies also across size classes or an interaction of industry variables with size classes. The purpose is, indeed, to investigate whether a certain industry variable has a differential effect on wages or productivity for different size classes with respect to the reference class. We do so by augmenting the specifications in Equation (5) as follows:

$$
y_{c j s t}=\mathbf{D}_{c j s t}^{\prime} \beta+m_{c j s t} \mathbf{D}_{c j s t}^{\prime} \gamma+x_{c j(s) t} \mathbf{D}_{c j s t}^{\prime} \eta+x_{c j(s) t} m_{c j s t} \mathbf{D}_{c j s t}^{\prime} \xi\left(+x_{c j(s) t} m_{c j s t} \phi\right)+\boldsymbol{\theta}_{c j t}+\varepsilon_{c j s t},
$$

where $x_{c j(s) t}$ is a control variable that varies at the country-industry-time and possibly size class level. ${ }^{10}$

Table 4, 5, and 6 show the results for, respectively, wages, labour productivity, and multi-factor productivity. Each column reports the results controlling for a different variable, which is specified as title of each column. The coefficients of the interactions of the control variable with the size classes and with the sectoral dummy, as well as of the triple interactions, are omitted from the table to increase readability. ${ }^{11}$ The first and the last column report results for the control variables that vary at the size class level, and come from the MultiProd database, i.e.: the average capital-labour ratio; and the average firm age. ${ }^{12}$ The other columns investigate the 
robustness of the results to selected country-industry-time variables, and specifically their differential impact across size classes in each macro-sector. In particular, we control for: the share of hours worked by high skilled workers; a measure of intangible ICT intensity (software and databases investments in non residential gross fixed capital formation); the log of R\&D expenditures; a measure of concentration in the industry, the Herfindahl index (HHI). ${ }^{13}$

Results in Column 1 of Table 4 show that, while the capital-labour ratio slightly reduces the size-premium in manufacturing, it strengthens the estimated size-wage premium in services. A significantly positive "service premium" is indeed found for firms with less than 250 employees, whereas a negative coefficient persists for large firms. Very similar results are found when controlling for skill, software, and R\&D intensity (Columns 2-4). Controlling for concentration, instead, does not seem to strongly affect the baseline results. Finally, the size-wage premium in manufacturing is strengthened once we control for the average firms' age in the size class. This finding points to the fact that larger firms tend to be older and, at the same time, older firms tend to pay on average lower wages; hence, the size-wage premium appears to be dampened when not controlling for age. This pattern seems to be even stronger in services. In fact, Column 6 of Table 4 shows that small and medium-small service firms pay a premium with respect to manufacturing that is larger than the one in the baseline. Moreover, large service firms do not pay anymore lower wages compared to equally sized manufacturing firms. This result differs from what we find when analysing productivity (see Table 5 and 6), as well as when we investigate the channels of the size-wage premium using French microdata, where results are very robust to controlling for firm age and wages are typically positively correlated with age (see Berlingieri et al., 2018). However, evidence in literature points to the fact that the link between wages and age is not monotonic, with wages falling and then rising with years in business (Brown and J. L. Medoff, 2003). Given the subtle relationship, one might need to be cautious when considering the firms' average age in a certain size class, whereas adding age as control variable at micro level seems to be more appropriate, as we do in our companion paper.

Table 4. Robustness of wages by size classes

\begin{tabular}{|c|c|c|c|c|c|c|}
\hline & $\begin{array}{c}(1) \\
\text { K-L Ratio }\end{array}$ & $\begin{array}{c}\text { (2) } \\
\text { H-Skill Sh. }\end{array}$ & $\begin{array}{c}\text { (3) } \\
\text { Soft. Int. }\end{array}$ & $\begin{array}{c}\text { (4) } \\
\text { R\&D. Int. }\end{array}$ & $\begin{array}{l}(5) \\
\mathrm{HHI}\end{array}$ & $\begin{array}{c}(6) \\
\text { Firm Age }\end{array}$ \\
\hline Small (10-19) & $\begin{array}{c}0.221^{* * *} \\
(0.008)\end{array}$ & $\begin{array}{c}0.159^{* * *} \\
(0.005)\end{array}$ & $\begin{array}{c}0.179^{* * *} \\
(0.004)\end{array}$ & $\begin{array}{c}0.199^{* * *} \\
(0.004)\end{array}$ & $\begin{array}{c}0.318^{* * *} \\
(0.016)\end{array}$ & $\begin{array}{c}0.387^{* * *} \\
(0.028)\end{array}$ \\
\hline MediumSmall (20-49) & $\begin{array}{c}0.314^{* * *} \\
(0.008)\end{array}$ & $\begin{array}{c}0.202^{* * *} \\
(0.007)\end{array}$ & $\begin{array}{c}0.249^{* * *} \\
(0.005)\end{array}$ & $\begin{array}{c}0.280^{* * *} \\
(0.005)\end{array}$ & $\begin{array}{c}0.391^{* * *} \\
(0.017)\end{array}$ & $\begin{array}{c}0.562^{* * *} \\
(0.040)\end{array}$ \\
\hline Medium (50-249) & $\begin{array}{c}0.461^{* * *} \\
(0.009)\end{array}$ & $\begin{array}{c}0.296^{* * *} \\
(0.008)\end{array}$ & $\begin{array}{c}0.343^{* * *} \\
(0.006)\end{array}$ & $\begin{array}{c}0.402^{* * *} \\
(0.006)\end{array}$ & $\begin{array}{c}0.497^{* * *} \\
(0.018)\end{array}$ & $\begin{array}{c}0.759^{* * *} \\
(0.050)\end{array}$ \\
\hline Large (250+) & $\begin{array}{c}0.671^{* * *} \\
(0.014)\end{array}$ & $\begin{array}{c}0.473^{* * *} \\
(0.009)\end{array}$ & $\begin{array}{c}0.503^{* * *} \\
(0.007)\end{array}$ & $\begin{array}{c}0.569^{* * *} \\
(0.007)\end{array}$ & $\begin{array}{c}0.663^{* * *} \\
(0.018)\end{array}$ & $\begin{array}{c}1.095^{* * *} \\
(0.059)\end{array}$ \\
\hline Small $(10-19) \times$ Market Services & $\begin{array}{c}0.098^{* * *} \\
(0.018)\end{array}$ & $\begin{array}{c}0.081^{* * *} \\
(0.010)\end{array}$ & $\begin{array}{c}0.057^{* * *} \\
(0.009)\end{array}$ & $\begin{array}{c}0.028^{* * *} \\
(0.009)\end{array}$ & $\begin{array}{c}0.010 \\
(0.027)\end{array}$ & $\begin{array}{l}0.166^{* *} \\
(0.076)\end{array}$ \\
\hline MediumSmall (20-49) $\times$ Market Services & $\begin{array}{c}0.111^{* * *} \\
(0.020)\end{array}$ & $\begin{array}{c}0.102^{* * *} \\
(0.012)\end{array}$ & $\begin{array}{c}0.049^{* * *} \\
(0.011)\end{array}$ & $\begin{array}{c}0.008 \\
(0.011)\end{array}$ & $\begin{array}{c}0.040 \\
(0.029)\end{array}$ & $\begin{array}{l}0.181^{*} \\
(0.103)\end{array}$ \\
\hline Medium $(50-249) \times$ Market Services & $\begin{array}{l}0.058^{* *} \\
(0.023)\end{array}$ & $\begin{array}{c}0.056^{* * *} \\
(0.015)\end{array}$ & $\begin{array}{c}0.001 \\
(0.014)\end{array}$ & $\begin{array}{c}-0.073^{* * *} \\
(0.013)\end{array}$ & $\begin{array}{c}0.020 \\
(0.032)\end{array}$ & $\begin{array}{c}0.159 \\
(0.129)\end{array}$ \\
\hline Large $(250+) \times$ Market Services & $\begin{array}{c}-0.180^{* * *} \\
(0.025)\end{array}$ & $\begin{array}{c}-0.103^{* * *} \\
(0.014)\end{array}$ & $\begin{array}{c}-0.166^{* * *} \\
(0.014)\end{array}$ & $\begin{array}{c}-0.227^{* * *} \\
(0.014)\end{array}$ & $\begin{array}{c}-0.117^{* * *} \\
(0.034)\end{array}$ & $\begin{array}{l}-0.022 \\
(0.155)\end{array}$ \\
\hline Observations & 18239 & 17098 & 18021 & 16704 & 17193 & 13878 \\
\hline Adj. R-Square & 0.975 & 0.957 & 0.956 & 0.957 & 0.964 & 0.974 \\
\hline Country-sector-year FE & Yes & Yes & Yes & Yes & Yes & Yes \\
\hline Num. Countries & 16 & 14 & 14 & 16 & 15 & 12 \\
\hline
\end{tabular}


Results for productivity are displayed in Table 5 (LP) and 6 (MFP). Overall they confirm that the correlation between productivity and size is weaker in the service sector, particularly for labour productivity (Table 5). The large and significant negative interaction coefficient for Medium and Large service firms implies that the relationship between LP and size is much weaker in services at the top, as already shown in Figure 2. There is indeed no positive productivity differential for firms in the "large" size class vis-à-vis those in the "medium" size class in services, while there is a clear positive premium in manufacturing. ${ }^{14}$ The size-LP premium is slightly dampened in manufacturing when controlling for the capital-labour ratio (Column 1), the high-skilled share (Column 2), and age (Column 6). The results are quite intuitive; they highlight that size is positively correlated with capital and skill intensities, as well as age, which in turn are positively linked to productivity. Software, R\&D intensity, and HHI (Columns 3-5) do not seem to affect the baseline results.

Table 5. Robustness of labour productivity by size classes

\begin{tabular}{|c|c|c|c|c|c|c|}
\hline & $\begin{array}{c}(1) \\
\text { K-L Ratio }\end{array}$ & $\begin{array}{c}\text { (2) } \\
\text { H-Skill Sh. }\end{array}$ & $\begin{array}{c}\text { (3) } \\
\text { Soft. Int. }\end{array}$ & $\begin{array}{c}(4) \\
\text { R\&D. Int. }\end{array}$ & $\begin{array}{c}(5) \\
\mathrm{HHI}\end{array}$ & $\begin{array}{c}(6) \\
\text { Firm Age }\end{array}$ \\
\hline Small (10-19) & $\begin{array}{c}0.222^{* * *} \\
(0.004)\end{array}$ & $\begin{array}{c}0.039^{* * *} \\
(0.005)\end{array}$ & $\begin{array}{c}0.135^{* * *} \\
(0.007)\end{array}$ & $\begin{array}{c}0.149^{* * *} \\
(0.007)\end{array}$ & $\begin{array}{c}0.105^{* * *} \\
(0.005)\end{array}$ & $\begin{array}{c}0.012 \\
(0.012)\end{array}$ \\
\hline MediumSmall (20-49) & $\begin{array}{c}0.281^{* * *} \\
(0.005)\end{array}$ & $\begin{array}{c}0.109^{* * *} \\
(0.008)\end{array}$ & $\begin{array}{c}0.238^{* * *} \\
(0.008)\end{array}$ & $\begin{array}{c}0.258^{* * *} \\
(0.008)\end{array}$ & $\begin{array}{c}0.184^{* * *} \\
(0.006)\end{array}$ & $\begin{array}{c}0.072^{* * *} \\
(0.015)\end{array}$ \\
\hline Medium (50-249) & $\begin{array}{c}0.336^{* * *} \\
(0.008)\end{array}$ & $\begin{array}{c}0.204^{* * *} \\
(0.010)\end{array}$ & $\begin{array}{c}0.350^{* * *} \\
(0.009)\end{array}$ & $\begin{array}{c}0.394^{* * *} \\
(0.010)\end{array}$ & $\begin{array}{c}0.292^{* * *} \\
(0.007)\end{array}$ & $\begin{array}{c}0.189^{* * *} \\
(0.018)\end{array}$ \\
\hline Large $(250+)$ & $\begin{array}{c}0.436^{* * *} \\
(0.014)\end{array}$ & $\begin{array}{c}0.431^{* * *} \\
(0.010)\end{array}$ & $\begin{array}{c}0.553^{* * *} \\
(0.010)\end{array}$ & $\begin{array}{c}0.594^{* * *} \\
(0.010)\end{array}$ & $\begin{array}{c}0.532^{* * *} \\
(0.008)\end{array}$ & $\begin{array}{c}0.422^{* * *} \\
(0.023)\end{array}$ \\
\hline Small $(10-19) \times$ Market Services & $\begin{array}{c}0.014 \\
(0.012)\end{array}$ & $\begin{array}{c}0.112^{* * *} \\
(0.010)\end{array}$ & $\begin{array}{c}0.018 \\
(0.013)\end{array}$ & $\begin{array}{c}0.015 \\
(0.014)\end{array}$ & $\begin{array}{c}-0.054^{* * *} \\
(0.014)\end{array}$ & $\begin{array}{c}0.070 \\
(0.043)\end{array}$ \\
\hline MediumSmall (20-49) $\times$ Market Services & $\begin{array}{c}0.014 \\
(0.013)\end{array}$ & $\begin{array}{c}0.088^{* * *} \\
(0.013)\end{array}$ & $\begin{array}{c}-0.043^{* * *} \\
(0.014)\end{array}$ & $\begin{array}{c}-0.050^{* * *} \\
(0.015)\end{array}$ & $\begin{array}{c}-0.064^{* * *} \\
(0.015)\end{array}$ & $\begin{array}{c}0.044 \\
(0.058)\end{array}$ \\
\hline Medium (50-249) $\times$ Market Services & $\begin{array}{l}-0.017 \\
(0.015)\end{array}$ & $\begin{array}{c}0.011 \\
(0.016)\end{array}$ & $\begin{array}{c}-0.155^{* * *} \\
(0.018)\end{array}$ & $\begin{array}{c}-0.186^{* * *} \\
(0.019)\end{array}$ & $\begin{array}{c}-0.129^{* * *} \\
(0.016)\end{array}$ & $\begin{array}{l}-0.053 \\
(0.072)\end{array}$ \\
\hline Large $(250+) \times$ Market Services & $\begin{array}{c}-0.192^{* * *} \\
(0.020)\end{array}$ & $\begin{array}{c}-0.207^{* * *} \\
(0.021)\end{array}$ & $\begin{array}{c}-0.381^{* * *} \\
(0.024)\end{array}$ & $\begin{array}{c}-0.398^{* * *} \\
(0.027)\end{array}$ & $\begin{array}{c}-0.319^{* * *} \\
(0.019)\end{array}$ & $\begin{array}{c}-0.352^{* * *} \\
(0.088)\end{array}$ \\
\hline Observations & 18042 & 16908 & 17824 & 16514 & 17005 & 13874 \\
\hline Adj. R-Square & 0.975 & 0.960 & 0.953 & 0.945 & 0.971 & 0.971 \\
\hline Country-sector-year FE & Yes & Yes & Yes & Yes & Yes & Yes \\
\hline Num. Countries & 16 & 14 & 14 & 16 & 15 & 12 \\
\hline
\end{tabular}

Similar results are found for MFP (Table 6), with the exception of high skill intensity (Column 1). When controlling for high-skill intensity, results for manufacturing are essentially unaffected, whereas the size premium increases in services. As a consequence, the negative differential for large firms disappears and the size-productivity premium is not significantly different between manufacturing and services. The downward bias in the baseline results might indicate that large service firms are not necessarily more high-skill intensive than smaller ones, or, alternatively, that small service firms are relatively skill intensive. Overall, the results suggest that the difference in the size-MFP premium between manufacturing and services can be partially explained by the skill composition. At the same time, by using a sectoral-level variable for high-skill intensity, we are asking a lot to the data as the results entirely hinge on the interaction with the size classes. A more detailed analysis performed using a more precise measure of skills is needed to shed more light on this issue. ${ }^{15}$ Finally, we find a weaker relationship with size with respect to the baseline when controlling for age: the productivity-size relationship becomes weaker in manufacturing but even more so in services, with the interaction terms significantly negative in all size classes. 
Table 6. Robustness of multi-factor productivity by size classes

\begin{tabular}{|c|c|c|c|c|c|}
\hline & $\begin{array}{c}(1) \\
\text { H-Skill Sh. }\end{array}$ & $\begin{array}{c}\text { (2) } \\
\text { Soft. Int. }\end{array}$ & $\begin{array}{c}(3) \\
\text { R\&D. Int. }\end{array}$ & $\begin{array}{c}(4) \\
\text { HHI }\end{array}$ & $\begin{array}{c}(5) \\
\text { Firm Age }\end{array}$ \\
\hline Small (10-19) & $\begin{array}{c}0.311^{\text {*** }} \\
(0.012)\end{array}$ & $\begin{array}{c}0.336^{* * *} \\
(0.008)\end{array}$ & $\begin{array}{c}0.334^{* * *} \\
(0.008)\end{array}$ & $\begin{array}{c}0.296^{* * *} \\
(0.009)\end{array}$ & $\begin{array}{c}0.197^{* * *} \\
(0.018)\end{array}$ \\
\hline MediumSmall (20-49) & $\begin{array}{c}0.516^{* * *} \\
(0.021)\end{array}$ & $\begin{array}{c}0.520^{* * *} \\
(0.012)\end{array}$ & $\begin{array}{c}0.510^{* * *} \\
(0.012)\end{array}$ & $\begin{array}{c}0.465^{* * *} \\
(0.015)\end{array}$ & $\begin{array}{c}0.283^{* * *} \\
(0.026)\end{array}$ \\
\hline Medium (50-249) & $\begin{array}{c}0.721^{* * *} \\
(0.029)\end{array}$ & $\begin{array}{c}0.731^{* * *} \\
(0.017)\end{array}$ & $\begin{array}{c}0.738^{* * *} \\
(0.017)\end{array}$ & $\begin{array}{c}0.662^{* * *} \\
(0.020)\end{array}$ & $\begin{array}{c}0.450^{* * *} \\
(0.034)\end{array}$ \\
\hline Large $(250+)$ & $\begin{array}{c}1.015^{* * *} \\
(0.036)\end{array}$ & $\begin{array}{c}1.076^{* * *} \\
(0.024)\end{array}$ & $\begin{array}{c}1.126^{* * *} \\
(0.026)\end{array}$ & $\begin{array}{c}1.003^{* * *} \\
(0.026)\end{array}$ & $\begin{array}{c}0.916^{* * *} \\
(0.049)\end{array}$ \\
\hline Small $(10-19) \times$ Market Services & $\begin{array}{c}0.095^{* * *} \\
(0.015)\end{array}$ & $\begin{array}{c}0.082^{* * *} \\
(0.013)\end{array}$ & $\begin{array}{c}0.095^{* * *} \\
(0.013)\end{array}$ & $\begin{array}{c}-0.026 \\
(0.019)\end{array}$ & $\begin{array}{c}-0.236^{* * *} \\
(0.043)\end{array}$ \\
\hline MediumSmall (20-49) $\times$ Market Services & $\begin{array}{c}0.062^{* *} \\
(0.024)\end{array}$ & $\begin{array}{c}0.071^{* * *} \\
(0.020)\end{array}$ & $\begin{array}{c}0.098^{* * *} \\
(0.020)\end{array}$ & $\begin{array}{c}-0.056^{* *} \\
(0.028)\end{array}$ & $\begin{array}{c}-0.354^{* * *} \\
(0.063)\end{array}$ \\
\hline Medium (50-249) $\times$ Market Services & $\begin{array}{c}0.040 \\
(0.035)\end{array}$ & $\begin{array}{c}0.028 \\
(0.031)\end{array}$ & $\begin{array}{c}0.040 \\
(0.031)\end{array}$ & $\begin{array}{l}-0.070 \\
(0.043)\end{array}$ & $\begin{array}{c}-0.611^{\text {*** }} \\
(0.092)\end{array}$ \\
\hline Large $(250+) \times$ Market Services & $\begin{array}{c}0.021 \\
(0.052)\end{array}$ & $\begin{array}{c}-0.115^{* *} \\
(0.056)\end{array}$ & $\begin{array}{c}-0.164^{* * *} \\
(0.059)\end{array}$ & $\begin{array}{c}-0.149^{* *} \\
(0.066)\end{array}$ & $\begin{array}{c}-1.325^{* * *} \\
(0.155)\end{array}$ \\
\hline Observations & 15644 & 16558 & 15399 & 16184 & 13014 \\
\hline Adj. R-Square & 0.988 & 0.987 & 0.986 & 0.988 & 0.993 \\
\hline Country-sector-year FE & Yes & Yes & Yes & Yes & Yes \\
\hline Num. Countries & 14 & 14 & 16 & 15 & 12 \\
\hline
\end{tabular}

A final remark about the interpretation of these results is in order: since the control variables are not always available for all country-industry-year-(size) pairs, the comparison of the results becomes less straightforward due to the confounding effect of changes in sample size. ${ }^{16}$ On top of this, results for MFP ought to be taken with some caution, as they might also be affected by the quality of MFP estimates, and especially in the service sector, where the measurement of the capital stock might be more problematic. Finally, we acknowledge the existence of a large heterogeneity in non-financial market services. Different 2 digit sectors might behave very differently: some might show a tight relationship of wages and productivity with size similar to manufacturing, whereas others might exhibit an even flatter distribution of wages and productivity over the size classes, a characteristic of non-market services. To unveil this heterogeneity, we perform our baseline analysis (Equation 5) on a sample composed by manufacturing and each of the 2-digit service sectors at the time. The sign of the interaction between the service sector and the Large firms category is reported in the Appendix (Table A.5).

\subsection{Variation over time}

There is mounting evidence that points to a decrease of the size premium over time (Hollister, 2004; Cobb and Lin, 2017). In the light of our results, this trend could be the consequence of a compositional effect induced by structural transformation: the fall of the overall size premium may come from the rising share of the service sector, for which the size premium is much weaker than manufacturing. Our data are not particularly well suited to test this hypothesis, as structural trends need long time series, which are very hard to collect across many countries. 
Moreover our sample is unbalanced, with countries entering in the sample in different years, which makes it hard to disentangle changes in trends from compositional effects coming from changes in the sample. Nevertheless, in this section we stretch our data to the maximum and test whether there is a change in the size premium over time, at least in recent years. To do so we augment our baseline specification in Equation (4) with further interactions for pre- and post-2007 period. We focus on the change in 2007 since our sample is more balanced in the second part of the period. The clear drawback is that we cannot distinguish a potential short term effect induced by the crisis from more long structural trends, but the results may still be informative no matter which of the two interpretations one might want to give to the results.

Table 7. The size premium over time

\begin{tabular}{|c|c|c|c|}
\hline & $\begin{array}{c}(1) \\
\ln (W)\end{array}$ & $\begin{array}{c}(2) \\
\ln (\mathrm{LP})\end{array}$ & $\begin{array}{c}(3) \\
\ln (\mathrm{MFP}+\mathrm{W})\end{array}$ \\
\hline Small (10-19) & $\begin{array}{c}0.222^{* * *} \\
(0.009)\end{array}$ & $\begin{array}{c}0.133^{* * *} \\
(0.009)\end{array}$ & $\begin{array}{c}0.347^{* * *} \\
(0.010)\end{array}$ \\
\hline MediumSmall (20-49) & $\begin{array}{c}0.302^{* * *} \\
(0.011)\end{array}$ & $\begin{array}{c}0.227^{* * *} \\
(0.010)\end{array}$ & $\begin{array}{c}0.525^{* * *} \\
(0.015)\end{array}$ \\
\hline Medium (50-249) & $\begin{array}{c}0.428^{* * *} \\
(0.012)\end{array}$ & $\begin{array}{c}0.368^{* * *} \\
(0.012)\end{array}$ & $\begin{array}{c}0.764^{* * *} \\
(0.020)\end{array}$ \\
\hline Large $(250+)$ & $\begin{array}{c}0.602^{* * *} \\
(0.014)\end{array}$ & $\begin{array}{c}0.593^{* * *} \\
(0.012)\end{array}$ & $\begin{array}{c}1.112^{* * *} \\
(0.027)\end{array}$ \\
\hline Small $(10-19) \times$ Post2007 & $\begin{array}{c}0.070^{* * *} \\
(0.023)\end{array}$ & $\begin{array}{l}0.028^{*} \\
(0.015)\end{array}$ & $\begin{array}{c}-0.045^{* * *} \\
(0.016)\end{array}$ \\
\hline MediumSmall (20-49) × Post2007 & $\begin{array}{c}0.071^{* * *} \\
(0.023)\end{array}$ & $\begin{array}{c}0.052^{* * *} \\
(0.018)\end{array}$ & $\begin{array}{l}-0.040^{*} \\
(0.023)\end{array}$ \\
\hline Medium $(50-249) \times$ Post2007 & $\begin{array}{l}0.051^{* *} \\
(0.022)\end{array}$ & $\begin{array}{c}0.009 \\
(0.019)\end{array}$ & $\begin{array}{c}-0.105^{* * *} \\
(0.028)\end{array}$ \\
\hline Large $(250+) \times$ Post 2007 & $\begin{array}{l}0.046^{*} \\
(0.024)\end{array}$ & $\begin{array}{l}-0.020 \\
(0.019)\end{array}$ & $\begin{array}{c}-0.200^{* * *} \\
(0.038)\end{array}$ \\
\hline Small $(10-19) \times$ Market Services & $\begin{array}{c}0.057^{* * *} \\
(0.021)\end{array}$ & $\begin{array}{c}0.020 \\
(0.016)\end{array}$ & $\begin{array}{l}0.043^{* *} \\
(0.018)\end{array}$ \\
\hline MediumSmall (20-49) $\times$ Market Services & $\begin{array}{l}0.045^{*} \\
(0.025)\end{array}$ & $\begin{array}{l}-0.029 \\
(0.018)\end{array}$ & $\begin{array}{c}0.025 \\
(0.028)\end{array}$ \\
\hline Medium $(50-249) \times$ Market Services & $\begin{array}{c}0.005 \\
(0.031)\end{array}$ & $\begin{array}{c}-0.133^{* * *} \\
(0.022)\end{array}$ & $\begin{array}{l}-0.076^{*} \\
(0.043)\end{array}$ \\
\hline Large $(250+) \times$ Market Services & $\begin{array}{c}-0.144^{* * *} \\
(0.032)\end{array}$ & $\begin{array}{c}-0.349^{* * *} \\
(0.026)\end{array}$ & $\begin{array}{c}-0.229^{* * *} \\
(0.067)\end{array}$ \\
\hline Micro (1-9) $\times$ Post2007 $\times$ Market Services & $\begin{array}{c}0.022 \\
(0.015)\end{array}$ & $\begin{array}{c}-0.061^{* * *} \\
(0.016)\end{array}$ & $\begin{array}{c}-0.071^{* * *} \\
(0.017)\end{array}$ \\
\hline Small $(10-19) \times$ Post2007 $\times$ Market Services & $\begin{array}{c}0.021 \\
(0.035)\end{array}$ & $\begin{array}{c}-0.059^{* *} \\
(0.024)\end{array}$ & $\begin{array}{c}-0.100^{* * *} \\
(0.024)\end{array}$ \\
\hline MediumSmall (20-49) $\times$ Post2007 × Market Services & $\begin{array}{c}0.056 \\
(0.042)\end{array}$ & $\begin{array}{c}-0.077^{* * *} \\
(0.026)\end{array}$ & $\begin{array}{c}-0.151^{* * *} \\
(0.040)\end{array}$ \\
\hline Medium $(50-249) \times$ Post2007 $\times$ Market Services & $\begin{array}{c}0.039 \\
(0.044)\end{array}$ & $\begin{array}{c}-0.100^{* * *} \\
(0.030)\end{array}$ & $\begin{array}{c}-0.133^{* *} \\
(0.058)\end{array}$ \\
\hline Large $(250+) \times$ Post $2007 \times$ Market Services & $\begin{array}{l}-0.002 \\
(0.046)\end{array}$ & $\begin{array}{c}-0.166^{* * *} \\
(0.041)\end{array}$ & $\begin{array}{l}-0.185^{*} \\
(0.100)\end{array}$ \\
\hline Observations & 20297 & 20105 & 18769 \\
\hline Adj. R-Square & 0.968 & 0.955 & 0.989 \\
\hline Country-sector Year FE & YES & YES & YES \\
\hline Num. Countries & 17 & 17 & 17 \\
\hline
\end{tabular}


Table 7 reports the results of the exercise. The coefficients of the individual size classes and their interaction with the service sector dummy confirm the results already seen in Table 3 . The coefficients of the interaction terms with the Post2007 dummy seem to confirm that there has been a weakening of the size premium in recent years, but this is mainly true for productivity in the service sector. In fact, in manufacturing, the interaction terms of the Medium and Large size classes are significantly negative (and increasing in absolute value) only for MFP. They are insignificant for LP, while, for wages, there appears to be an increase of the wage premium for all size classes, which implies that the size premium relative to Micro firms shifts up. However, the increase of wage premium is decreasing over the size classes. The weakening of the size premium appears to be stronger in services, for both LP and MFP. The interaction terms with the Post2007 dummy are significantly negative for all the size classes, and particularly so at the top, implying that the link between productivity and size is weaker in services compared to manufacturing after 2007. For wages, instead, they are all insignificant, implying that there are not sectoral differences in the post 2007 wage-size profile. 


\section{The productivity-wage premium}

Having found a significantly weaker size premium for both wages and productivity in the service sector compared to manufacturing, we now turn to investigating the direct link between wages and productivity. We ask ourselves whether wages respond more to firms' productivity compared to size, and whether the relationship is similar across sectors. Once again we focus on this relationship within countries, 2-digit sectors and years. Therefore, we adopt an econometric approach similar to that described in Section 3, the difference being that now our dummy variables represent 5 bins of the productivity distribution $\left(1^{\text {st }}\right.$ to $10^{\text {th }}, 10^{\text {th }}$ to $40^{\text {th }}, 40^{\text {th }}$ to $60^{\text {th }}, 60^{\text {th }}$ to $90^{\text {th }}$, and $90^{\text {th }}$ to $100^{\text {th }}$ percentile of the productivity distribution), instead of 5 size classes. This exercise exploits another feature of the MultiProd project, which also collects firm characteristics by different sections of the productivity distributions.

Figure 3 shows the results of regressions that consider separately manufacturing and non-financial market services. ${ }^{17}$ Conversely to size, average wages are increasing with productivity in both manufacturing and non-financial market services, even after controlling for country-sector characteristics and overall time trends. If anything, the figure shows that the link between wages and productivity is tighter in services compared to manufacturing, in contrast to the relationship with size.

To further explore differences between manufacturing and non-financial market services, we also mirror Equation (4) and Equation (5), but using as right hand side variables the productivity bins instead of size classes. Results are shown in Table 8. The higher the productivity percentile (both in terms of LP and MFP), the larger the wage differential, as the coefficients in the first four rows of the table show. This result confirms that in manufacturing there is also a strong productivity-wage premium besides the size-wage premium shown in the previous section. Whether the productivity-wage premium is stronger or weaker compared to the size-wage premium is not easy to say as the productivity and size classes do not capture the same share of firms, hence both the comparison of the magnitude of the coefficients as well as the interpretation of the slopes in Figure 3 is not straightforward. But we can conclude that in manufacturing the wage premium of firms at the productivity frontier (top decile) with respect to the laggards firms at the bottom of the distribution (bottom decile) is larger than the premium of large firms with respect to micro firms. The result is robust also when controlling for any unobservable characteristic that varies at the country-industry-time level, as the Columns 3 and 4 of the Table show.

In addition, and in contrast with the size-wage premium, we find that, within the same productivity bin, being in the service sector provides an extra wage premium with respect to manufacturing across all productivity quantiles, as the last four rows of Table 8 show. But what is more relevant for our argument is that the premium significantly increases over the productivity percentiles, for both LP and MFP. Overall these findings show that there is a tight and positive link between wages and productivity, and, contrary to the size-wage premium, this holds in both manufacturing and services. In particular we find that the correlation between wages and productivity is even stronger in the service sector compared to manufacturing.

The literature has typically investigated the size premium in terms of employment (see Oi and Idson, 1999), but it is legitimate to ask which is the best measure for the size of a firm. We repeat our analysis regressing wages on a different measure of size: quantiles of gross output. In particular, our explanatory variable now represents 3 bins of the gross output distribution $\left(1^{\text {st }}\right.$ to $10^{\text {th }}, 10^{\text {th }}$ to $90^{\text {th }}$, and $90^{\text {th }}$ to $\left.100^{\text {th }}\right)$. Results are shown in Figure A.4 and Table A.7: there is a tight and positive link between wages and gross output both in manufacturing and services. Moreover, the correlation is stronger in the service sector than manufacturing, and this result holds for almost every 2-digit service sector. ${ }^{18}$ Therefore the link that we find between wages and productivity already appears when size is defined in terms of sales, and not employment as typically done in the literature. This result is reminiscent of the findings in Autor et al. (2017b). They find a negative correlation between the labour share and concentration, if the latter is expressed in terms of sales. If, instead, concentration is expressed in terms of employment the correlation 
becomes positive. This result is explained by the fact that canonical superstar (service) firms such as Google or Facebook employ relatively few workers compared to their revenues. In other words, superstar firms grow "without mass", that is, mostly in terms of revenues rather than employment. This implies that the most productive firms are not necessarily the ones that hire the largest number of employees, a result that is essentially the other side of the coin with respect to our findings. In fact in services we find a rather flat link between wages and size expressed in terms of employment, but a tight and positive link of wages with both productivity and size expressed in terms of gross output.

Figure 3. Wages by productivity quantiles

(a) by LP quantiles

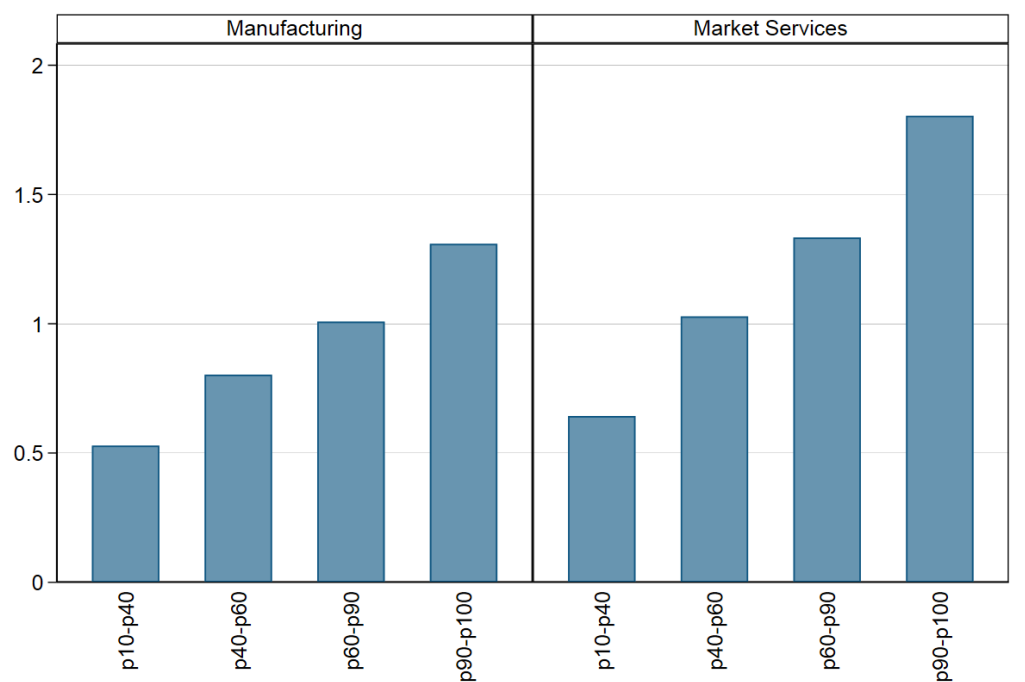

(b) by MFP quantiles

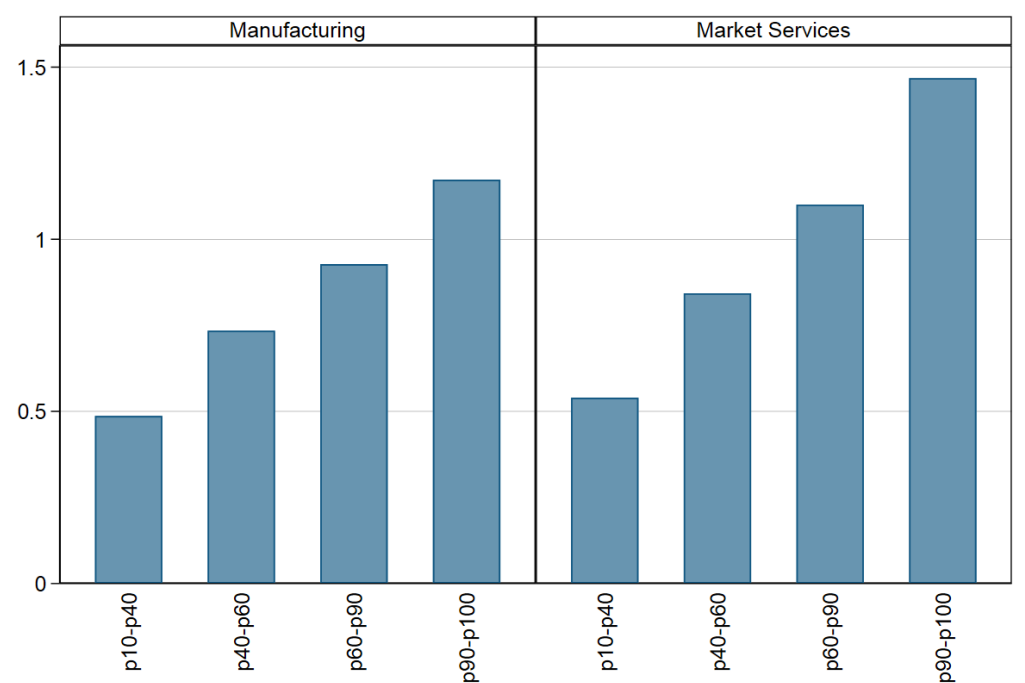

Note: The figure plots the estimated productivity dummies of a regression of log-wages within country-sector pairs and years. In particular, the productivity distribution has been split into 5 bins: $1^{\text {st }}$ to $10^{\text {th }}$ percentile, $10^{\text {th }}$ to $40^{\text {th }}, 40^{\text {th }}$ to $60^{\text {th }}, 60^{\text {th }}$ to $90^{\text {th }}$, and $90^{\text {th }}$ to $100^{\text {th }}$. Data used include the following countries: AUS, AUT, BEL, CAN, CHE, CHL, DEU,DNK, FIN, FRA, HUN, ITA, JPN, NLD, NOR, PRT, SWE. 
Table 8. Wages by productivity quantiles

\begin{tabular}{lcccc}
\hline & $(1)$ & $(2)$ & $(3)$ & $(4)$ \\
& $\ln (\mathrm{LP})$ & $\ln (\mathrm{MFP})$ & $\ln (\mathrm{LP})$ & $\ln (\mathrm{MFP})$ \\
\hline p10-p40 & $0.529^{* * *}$ & $0.487^{* * *}$ & $0.529^{* * *}$ & $0.487^{* * *}$ \\
& $(0.007)$ & $(0.008)$ & $(0.007)$ & $(0.008)$ \\
p40-p60 & $0.803^{* * *}$ & $0.734^{* * *}$ & $0.803^{* * *}$ & $0.734^{* * *}$ \\
& $(0.011)$ & $(0.011)$ & $(0.011)$ & $(0.011)$ \\
p60-p90 & $1.008^{* * *}$ & $0.928^{* * *}$ & $1.009^{* * *}$ & $0.927^{* * *}$ \\
& $(0.012)$ & $(0.012)$ & $(0.012)$ & $(0.012)$ \\
p90-p100 & $1.309^{* * *}$ & $1.173^{* * *}$ & $1.311^{* * *}$ & $1.174^{* * *}$ \\
& $(0.013)$ & $(0.012)$ & $(0.013)$ & $(0.012)$ \\
p10-p40 $\times$ Market Services & $0.115^{* * *}$ & $0.053^{* * *}$ & $0.115^{* * *}$ & $0.053^{* * *}$ \\
& $(0.012)$ & $(0.011)$ & $(0.012)$ & $(0.011)$ \\
p40-p60 $\times$ Market Services & $0.225^{* * *}$ & $0.109^{* * *}$ & $0.226^{* * *}$ & $0.109^{* * *}$ \\
p60-p90 $\times$ Market Services & $(0.019)$ & $(0.016)$ & $(0.019)$ & $(0.016)$ \\
& $0.325^{* * *}$ & $0.173^{* * *}$ & $0.326^{* * *}$ & $0.174^{* * *}$ \\
p90-p100 $\times$ Market Services & $(0.025)$ & $(0.017)$ & $(0.025)$ & $(0.017)$ \\
& $0.495^{* * *}$ & $0.295^{* * *}$ & $0.495^{* * *}$ & $0.296^{* * *}$ \\
\hline Observations & $(0.034)$ & $(0.019)$ & $(0.033)$ & $(0.019)$ \\
Adj. R-Square & 20108 & 19341 & 20022 & 19286 \\
Country-sector Year FE & 0.969 & 0.979 & 0.965 & 0.977 \\
Country-sector-year FE & YES & YES & & YES \\
Num. Countries & 17 & 17 & 17 & 17 \\
\hline
\end{tabular}

Clustered standard errors at the country-sector-year level in parentheses: ${ }^{*} p<0.1,{ }^{* *} p<0.05,{ }^{* * *} p<0.01$.

The set of countries include:AUS,AUT,BEL,CAN,CHE,CHL,DEU,DNK,FIN,FRA,HUN,ITA,JPN,NLD,NOR,PRT,SWE.

Finally, in analogy with what we have done in Section 3.2, we check the robustness of these findings to a series of potentially omitted variables that might be correlated with productivity and, at the same time, affect wages. We use exactly the same control variables used before: the average capital-labour ratio; the share of hours worked by high skilled workers; a measure of intangible ICT intensity (software and databases investments in non residential gross fixed capital formation); the $\log$ of R\&D expenditures; a measure of concentration in the industry, the Herfindahl index (HHI); and the average firm age. Results are reported in Table A.8 and A.9 of the Appendix. Overall, the robustness checks confirm our results: the positive correlation between wages and productivity is very robust across all specifications, for both manufacturing and market services. Moreover, the positive correlation is stronger in services than in manufacturing, and the higher the productivity percentile, the larger the wage differential. 


\section{Conclusions and next steps}

Most of the existing theoretical and empirical literature has documented: i) a positive correlation between firms' productivity and size, i.e., bigger firms are on average more productive than smaller ones; ii) the so-called "size-wage premium", i.e., workers at larger firms receive on average higher wages. However, most of these findings have been established using manufacturing data, without considering the service sector, which nowadays accounts for most of the value added and employment in OECD countries.

In this paper we contribute to this literature exploiting a novel dataset that contains harmonised micro-aggregated statistics on firms' productivity, wages, and size for 24 countries over the last two decades. Thanks to this unique data source collected in the context of the OECD MultiProd project, we are able to explore the relationship between size, wages, and productivity in both manufacturing and non-financial market services, as well as compare the two.

The main results of this paper can be summarised as follows. First, in the manufacturing sector, we find that both productivity and wages increase with firms' size, confirming the large evidence already provided by the literature. Second, in contrast to manufacturing, the size premium is much weaker in the service sector: productivity and wages display a significantly flatter pattern across size classes. Third, if we link wages to productivity instead of size, we find that they increase monotonically with productivity in both manufacturing and especially non-financial market services, where the correlation between wages and productivity is stronger than in manufacturing. Overall, these results suggest that, when looking beyond manufacturing, we might be in the presence of a "productivity-wage premium" rather than a "size-wage premium".

These results have first-order policy implications for both workers and firms. Given the large share of services in our economies, the fact that the number of employees is much less important in the service sector calls for a reconsideration of the use of employment as the main, if not only, component in the size definition adopted in the design of many policies that are size based. Our results show that the SMEs categorisation (firms with less than 250 employees) is less meaningful in the service sector, as there might exist SMEs with very high levels of productivity and paying very high wages. Policies based on simple measures such as value added (or even sales) per worker might be more promising in targeting the right firms. Moreover policies that try to address the gap in capital, ICT and R\&D intensities in services might go a long way in closing the productivity gap with respect to manufacturing (especially for large firms), which can have important implications for aggregate productivity given their large weights in the economy. These facts call for a reconsideration of industrial policy design, which should reflect the evolving structure of our economies and consider the implications for an inclusive model of growth in the context of the new service economy. At the same time, our findings show that policy makers should be cautious in using common measures of allocative efficiency based on the positive relationship of productivity and wages with size. In the service sector these measures typically indicate a low level of allocative efficiency, but whether this is due to real inefficiencies or to structural differences is still an open question that deserves further study.

The MultiProd dataset allows us to test the existence of these stylised facts over a large set of countries. However, given its micro-aggregated nature, we cannot investigate the underlying micro-mechanisms in greater detail. In a companion paper (Berlingieri et al., 2018), we study what affects the link between size, productivity, and wages at the micro level using French matched employer-employee data. This allows us to study what affects the link between the three (size, productivity, and wages) beyond standard industry-level variables, which are typically not available by size classes within sectors over time. In particular, firm level data allow for a more flexible specification of the size and productivity dimensions, as well as distinguishing, among other things, between firm and establishment size. Moreover, thanks to the link with worker level information, these data offer much more precise measures of wages, skills, and the possibility to control for other observable and unobservable workers' 
characteristics, which enable us to unveil the sources of the differential size (productivity) premia across sectors. At the firm level, we find for France very similar results to those shown in the present paper: while both wages and productivity exhibit a much more concave distribution over size in services than in manufacturing, the same in not true when looking at wages over the productivity distribution. 


\section{References}

Ackerberg, D., C. Lanier Benkard, S. Berry, and A. Pakes (Jan. 2007), "Econometric Tools for Analyzing Market Outcomes", in: Handbook of Econometrics, ed. by J. Heckman and E. Leamer, vol. 6, Handbook of Econometrics, Elsevier, chap. 63.

Albaek, K., M. Arai, R. Asplund, E. Barth, and E. Strojer Madsen (Dec. 1998), "Measuring wage effects of plant size”, Labour Economics, Vol. 5, No. 4, pp. 425-448.

Andrews, D., C. Criscuolo, and P. N. Gal (2016), "The Best versus the Rest: The Global Productivity Slowdown, Divergence across Firms and the Role of Public Policy", OECD Productivity Working Papers No. 5, OECD Publishing, Paris, DOI: https://doi.org/http://dx.doi.org/10.1787/63629cc9-en.

Autor, D., D. Dorn, L. Katz, C. Patterson, and J. van Reenen (2017a), "Concentrating on the Fall of the Labor Share", American Economic Review, Vol. 107, No. 5, pp. 180-85.

Autor, D., D. Dorn, L. Katz, C. Patterson, and J. van Reenen (May 2017b), "The Fall of the Labor Share and the Rise of Superstar Firms", Working Paper No. 23396, National Bureau of Economic Research.

Bajgar, M., G. Berlingieri, S. Calligaris, and C. Criscuolo (forthcoming), "Can Firm Micro Data Match Macro Trends? Comparing MultiProd and STAN", OECD Science, Technology and Industry Working Papers, OECD Publishing.

Bartelsman, E., J. Haltiwanger, and S. Scarpetta (2013), "Cross-country Differences in Productivity: The Role of Allocation and Selection", The American Economic Review, Vol. 103, No. 1, pp. 305-334.

Bartelsman, E., J. Haltiwanger, and S. Scarpetta (2009), "Measuring and Analyzing Cross-country Differences in Firm Dynamics", in: Producer Dynamics: New Evidence from Micro Data, University of Chicago Press, pp. 15-76.

Bartelsman, E., S. Scarpetta, and F. Schivardi (2005), "Comparative Analysis of Firm Demographics and Survival: Evidence from Micro-level Sources in OECD Countries", Industrial and Corporate Change, Vol. 14, No. 3, pp. 365-391.

Barth, E., J. Davis, and R. B. Freeman (2018), "Augmenting the Human Capital Earnings Equation with Measures of Where People Work", Journal of Labor Economics, Vol. 36, No. S1, S71-S97, DOI: https://doi.org/10.1086/694187.

Bayard, K. and K. R. Troske (May 1999), "Examining the Employer-Size Wage Premium in the Manufacturing, Retail Trade, and Service Industries Using Employer-Employee Matched Data", American Economic Review, Vol. 89, No. 2, pp. 99-103, DOI: https://doi.org/10.1257/aer.89.2.99.

Berlingieri, G., P. Blanchenay, S. Calligaris, and C. Criscuolo (2017a), "The MultiProd Project: a Comprehensive Overview", OECD Science, Technology and Industry Working Papers No. 2017/04, OECD Publishing, Paris, DOI: https://doi.org/10.1787/2069b6a3-en.

Berlingieri, G., P. Blanchenay, and C. Criscuolo (2017b), "The Great Divergence(s)", OECD Science, Technology and Industry Policy Papers No. 39, OECD Publishing, Paris, DOI: https://doi.org/10. 1787/953f3853-en.

Berlingieri, G., S. Calligaris, and C. Criscuolo (2018), "Does the Sector Matter? Unbundling the Size-Productivity-Wage Premium", Unpublished.

Brown, C. and J. Medoff (1989), "The Employer Size-Wage Effect", Journal of Political Economy, Vol. 97, No. 5, pp. 1027-59. 
Brown, C. and J. L. Medoff (2003), "Firm age and wages", Journal of Labor Economics, Vol. 21, No. 3, pp. 677-697.

Burdett, K. and D. Mortensen (1998), "Wage Differentials, Employer Size, and Unemployment", International Economic Review, Vol. 39, No. 2, pp. 257-73.

Card, D., A. R. Cardoso, J. Heining, and P. Kline (2018), "Firms and Labor Market Inequality: Evidence and Some Theory", Journal of Labor Economics, Vol. 36, No. S1, S13-S70, DOI: https://doi.org/10. $1086 / 694153$.

Cobb, J. A. and K.-H. Lin (2017), "Growing Apart: The Changing Firm-Size Wage Premium and Its Inequality Consequences”, Organization Science, Vol. 28, No. 3, pp. 429-446, DOI: https://doi.org/ 10.1287/orsc.2017.1125.

Haltiwanger, J., H. Hyatt, and E. McEntarfer (June 2015), "Cyclical Reallocation of Workers Across Employers by Firm Size and Firm Wage”, NBER Working Papers No. 21235, National Bureau of Economic Research, Inc.

Hollister, M. N. (2004), "Does Firm Size Matter Anymore? The New Economy and Firm Size Wage Effects", American Sociological Review, Vol. 69, No. 5, pp. 659-679, DOI: https://doi.org/10.1177/ 000312240406900503.

Kehrig, M. and N. Vincent (2017), "Growing Productivity without Growing Wages: The Micro-Level Anatomy of the Aggregate Labor Share Decline", CESifo Working Paper Series No. 6454, CESifo Group Munich.

Lucas, R. E. (1978), "On the size distribution of business firms", The Bell Journal of Economics, pp. 508-523.

Main, B. G. M. and B. Reilly (May 1993), "The Employer Size-Wage Gap: Evidence for Britain", Economica, Vol. 60, No. 238, pp. 125-142.

Manning, A. (Dec. 2011), "Imperfect Competition in the Labor Market", in: ed. by O. Ashenfelter and D. Card, vol. 4, Handbook of Labor Economics, Elsevier, chap. 11, pp. 973-1041.

Melitz, M. J. (2003), "The impact of trade on intra-industry reallocations and aggregate industry productivity", Econometrica, Vol. 71, No. 6, pp. 1695-1725.

Moore, H. L. (1911), Laws of wages: An essay in statistical economics, Macmillan.

Morissette, R. (1993), “Canadian jobs and firm size: do smaller firms pay less?”, Canadian Journal of Economics, pp. 159-174.

Moscarini, G. and F. Postel-Vinay (2016), “Did the Job Ladder Fail after the Great Recession?”, Journal of Labor Economics, Vol. 34, No. S1, S55-S93.

Moscarini, G. and F. Postel-Vinay (2013), "Stochastic Search Equilibrium”, Review of Economic Studies, Vol. 80, No. 4, pp. 1545-1581.

Moscarini, G. and F. Postel-Vinay (2009), “The Timing of Labor Market Expansions: New Facts and a New Hypothesis", in: NBER Macroeconomics Annual 2008, Volume 23, National Bureau of Economic Research, Inc, pp. 1-51.

Oi, W. Y. and T. L. Idson (1999), "Firm size and wages", Handbook of labor economics, Vol. 3, pp. 2165-2214.

Schmidt, C. M. and K. F. Zimmermann (Nov. 1991), "Work Characteristics, Firm Size and Wages", The Review of Economics and Statistics, Vol. 73, No. 4, pp. 705-710. 
Syverson, C. (2011), “What Determines Productivity?”, Journal of Economic Literature, Vol. 49, No. 2, pp. 326-365.

Timmer, M. P., E. Dietzenbacher, B. Los, R. Stehrer, and G. J. Vries (Aug. 2015), “ An Illustrated User Guide to the World Input-Output Database: the Case of the Global Automotive Production”, Review of International Economics, Vol. 23, No. 3, pp. 575-605.

Troske, K. (1999), "Evidence On The Employer Size-Wage Premium From Worker-Establishment Matched Data", The Review of Economics and Statistics, Vol. 81, No. 1, pp. 15-26.

Van Ark, B. and E. Monnikhof (1996), "Size Distribution of Output and Employment: A Data Set for Manufacturing Industries in Five OECD Countries", OECD Economics Department Working Papers No. 166, OECD Publishing, Paris, DOI: https://doi.org/10.1787/207105163036.

Wooldridge, J. M. (2009), “On Estimating Firm-Level Production Functions Using Proxy Variables to Control for Unobservables”, Economics Letters, Vol. 104, No. 3, pp. 112-114. 


\section{Notes}

${ }^{1}$ MultiProd, DynEmp, and MicroBeRD are projects carried forward by the Directorate for Science, Technology and Innovation (STI) at the OECD. The DynEmp (Dynamics of Employment) project provides harmonised micro-aggregated data to analyse employment dynamics (find out more: http://www.oecd.org/sti/dynemp.htm) and MicroBeRD provides information on R\&D activity in firms from official business R\&D surveys (find out more: http://www.oecd.org/sti/rd-tax-stats.htm).

${ }^{2}$ Further details about the representativeness of the MultiProd dataset, as well as a comparison the STAN dataset, can be found in Bajgar et al. (forthcoming).

3 The non-financial market service sector includes the following 2-digit sectors: Wholesale and retail trade, repair of motor vehicles and motorcycles; Transportation and storage; Accommodation and food service activities; Publishing, audiovisual and broadcasting activities; Telecommunications; IT and other information services; Legal and accounting activities; Scientific research and development; Advertising and market research, other professional, scientific and technical activities, veterinary activities; Administrative and support service activities.

${ }^{4}$ For the sake of maximising cross-country comparability we rely on headcounts (HC) for measuring labour input since it is the one most commonly available in the countries considered; only when HC is not available, we rely on full time equivalents (FTE).

${ }^{5}$ For the MFP calculations a measure of capital stock is needed. If information on investment is available, the capital input is measured through the Perpetual Inventory Method (PIM); otherwise, the deflated book value of capital is used.

${ }^{6}$ For a detailed discussion on control function approaches, see Ackerberg et al. (2007).

7 An analysis with matched employer-employee data has not been attempted because of the higher level of complexity that this would entail in terms of coordination both within and across countries, but most importantly because such an analysis would severely limit cross-country comparison as these data are not yet available in many countries. A future step of the MultiProd project will be to access matched employer-employee data for a subset of countries in which the data are available.

${ }^{8}$ Since the data in MultiProd are micro-aggregated moments (and means in particular) from firm-level data, in all regressions we weight each observation $c j s t$ by the number of firms reporting non-missing information for the relevant variable in a given country-sector-size class-year. The weighting strategy implies that our estimates are equivalent to those hypothetically generated using the underlying micro-data samples.

9 The corresponding table can be found in the Appendix, Table A.1.

${ }^{10}$ All control variables are standardised variables with a zero mean so that the coefficients of the size dummies can be interpreted as the size premium at the mean of the control variable.

${ }^{11}$ For standard industry-level control variables, which do not vary at the size class level, the interaction with the macro-sector indicator cannot be identified and is omitted.

12 See Berlingieri et al. (2017a) for the details about the definition of the variables. The capital-labour ratio has been included as control variable for wages and LP, but not for MFP, since the latter already accounts for capital inputs. In any case, controlling for the capital-labour ratio does not affect the results for MFP (the regression results are available upon request).

13 The data on skills are ISIC Revision 4 estimates based on the ISIC 3 original data from the World Input Output Database (WIOD), Socio Economic Accounts, July 2014 (See Timmer et al., 2015). ICT intensity is obtained mainly from the System of National Accounts (SNA) and complemented with EU-KLEMS data. This indicator is computed at the country-industry-year level and takes into account differences in prices of ICT and non-ICT assets by applying country-specific deflators. The R\&D variable refers to annual data on $R \& D$ expenditures by main activity of the enterprise carrying out $R \& D$, expressed in PPPs US dollars at 2010 constant prices. The data come from the OECD ANBERD (Analytical Business Enterprise Research and Development) database. The Herfindahl index has been computed using the MultiProd dataset. 
${ }^{14}$ For instance, looking at Column 1, the productivity premium of large firms in manufacturing is $44 \%$ compared to $34 \%$ for medium-sized firms. On the other hand, in services, the productivity premium of medium-sized firms is $32 \%(0.336-0.017)$ while for large firms is just $24 \%(0.436-0.192)$.

${ }^{15}$ In our companion paper (Berlingieri et al., 2018), we use French matched employer-employee data and find a significant difference in the size-MFP premium between manufacturing and services, even after controlling for the skill composition at the firm level.

16 To overcome this issue, we perform our baseline regressions (Columns 4-6 of Table 3) on the same sample used in each robustness check. Table A.2, A.3, and A.4 display each robustness check and the baseline on the corresponding sample for, respectively, wages, LP, and MFP. The results show that the change in the sample does not qualitatively affect the interpretation of the results.

17 The corresponding table can be found in the Appendix, Table A.6

${ }^{18}$ We perform a sectoral heterogeneity analysis similar to the robustness exercise in Section 3.2, and we find a positive and significant coefficient for the last bin of the GO distribution in each service sector except for "Scientific research and development". Results available upon request from the authors. 


\section{Appendix}

\section{A. Additional results}

Table A.1. Wages and productivity by size classes, manufacturing vs. services

\begin{tabular}{lcccccc}
\hline & $(1)$ & $(2)$ & $(3)$ & $(4)$ & $(5)$ & $(6)$ \\
& $\ln (\mathrm{W})$ Manuf & $\ln (\mathrm{W}) \operatorname{Serv}$ & $\ln (\mathrm{LP})$ Manuf & $\ln (\mathrm{LP})$ Serv & $\ln$ (MFP_W) Manuf. & $\ln (\mathrm{MFP}$ _W $)$ Serv \\
\hline Small (10-19) & $0.247^{* * *}$ & $0.307^{* * *}$ & $0.142^{* * *}$ & $0.165^{* * *}$ & $0.330^{* * *}$ & $0.361^{* * *}$ \\
& $(0.010)$ & $(0.019)$ & $(0.008)$ & $(0.012)$ & $(0.008)$ & $(0.014)$ \\
MediumSmall (20-49) & $0.327^{* * *}$ & $0.389^{* * *}$ & $0.247^{* * *}$ & $0.213^{* * *}$ & $0.513^{* * *}$ & $0.503^{* * *}$ \\
& $(0.011)$ & $(0.023)$ & $(0.009)$ & $(0.014)$ & $(0.013)$ & $(0.022)$ \\
Medium (50-249) & $0.445^{* * *}$ & $0.460^{* * *}$ & $0.370^{* * *}$ & $0.220^{* * *}$ & $0.726^{* * *}$ & $0.616^{* * *}$ \\
& $(0.013)$ & $(0.029)$ & $(0.010)$ & $(0.017)$ & $(0.018)$ & $(0.037)$ \\
Large (250+) & $0.618^{* * *}$ & $0.468^{* * *}$ & $0.585^{* * *}$ & $0.190^{* * *}$ & $1.043^{* * *}$ & $0.751^{* * *}$ \\
& $(0.014)$ & $(0.031)$ & $(0.010)$ & $(0.023)$ & $(0.024)$ & $(0.061)$ \\
\hline Observations & 11148 & 9149 & 10961 & 9144 & 10440 & 8329 \\
Adj. R-Square & 0.959 & 0.969 & 0.958 & 0.955 & 0.984 & 0.990 \\
Country-sector year FE & YES & YES & YES & YES & YES & YES \\
Num. Countries & 17 & 17 & 17 & 17 & 17 & 17 \\
\hline
\end{tabular}

Clustered standard errors at the country-sector-year level in parentheses: ${ }^{*} p<0.1,{ }^{* *} p<0.05,{ }^{* * *} p<0.01$.

The set of countries include:AUS,AUT,BEL,CAN,CHE,CHL,DEU,DNK,FIN,FRA,HUN,ITA,JPN,NLD,NOR,PRT,SWE.

Table A.2. Baseline and robustness of wages by size classes

\begin{tabular}{|c|c|c|c|c|c|c|c|c|c|c|c|c|}
\hline & $\begin{array}{c}\text { (1) } \\
\text { Bas. K-L Ratio }\end{array}$ & $\begin{array}{c}(2) \\
\text { K-L Ratio }\end{array}$ & $\begin{array}{c}\text { (3) } \\
\text { Bas. H-Skill Sh. }\end{array}$ & $\begin{array}{c}\text { (4) } \\
\text { H-Skill Sh. }\end{array}$ & $\begin{array}{c}(5) \\
\text { Bas. Soft. Int. }\end{array}$ & $\begin{array}{c}\text { (6) } \\
\text { Soft. Int. }\end{array}$ & $\begin{array}{c}(7) \\
\text { Bas. R\&D. Int. }\end{array}$ & $\begin{array}{c}\text { (8) } \\
\text { R\&D. Int. }\end{array}$ & $\begin{array}{c}\text { (9) } \\
\text { Bas. HHI }\end{array}$ & $\begin{array}{l}\text { (10) } \\
\text { HHI }\end{array}$ & $\begin{array}{l}\text { (11) } \\
\text { Bas. Firm Age }\end{array}$ & $\begin{array}{c}\text { (12) } \\
\text { Firm Age }\end{array}$ \\
\hline Small (10-19) & $\begin{array}{c}0.312^{* * *} \\
(0.014)\end{array}$ & $\begin{array}{l}0.221^{* * *} \\
(0.008)\end{array}$ & $\begin{array}{c}0.181^{* * *} \\
(0.004)\end{array}$ & $\begin{array}{c}0.159^{* * *} \\
(0.005)\end{array}$ & $\begin{array}{c}0.182^{* * *} \\
(0.004)\end{array}$ & $\begin{array}{c}0.179^{* * *} \\
(0.004)\end{array}$ & $\begin{array}{l}0.181^{* * *} \\
(0.004)\end{array}$ & $\begin{array}{c}0.199^{* * *} \\
(0.004)\end{array}$ & $\begin{array}{c}0.270^{* * *} \\
(0.013)\end{array}$ & $\begin{array}{c}0.318^{* * *} \\
(0.016)\end{array}$ & $\begin{array}{c}0.257^{* * *} \\
(0.012)\end{array}$ & $\begin{array}{c}0.387^{* * *} \\
(0.028)\end{array}$ \\
\hline MediumSmall (20-49) & $\begin{array}{l}0.411^{* * *} \\
(0.015)\end{array}$ & $\begin{array}{c}0.314^{* * *} \\
(0.008)\end{array}$ & $\begin{array}{c}0.254^{* * *} \\
(0.005)\end{array}$ & $\begin{array}{l}0.202^{* * *} \\
(0.007)\end{array}$ & $\begin{array}{c}0.252^{* * *} \\
(0.005)\end{array}$ & $\begin{array}{l}0.249^{* * *} \\
(0.005)\end{array}$ & $\begin{array}{l}0.253^{* * *} \\
(0.005)\end{array}$ & $\begin{array}{l}0.280^{* * *} \\
(0.005)\end{array}$ & $\begin{array}{c}0.340^{* * *} \\
(0.015)\end{array}$ & $\begin{array}{c}0.391^{* * *} \\
(0.017)\end{array}$ & $\begin{array}{c}0.343^{* * *} \\
(0.014)\end{array}$ & $\begin{array}{c}0.562^{* * *} \\
(0.040)\end{array}$ \\
\hline Medium (50-249) & $\begin{array}{c}0.548^{* * *} \\
(0.017)\end{array}$ & $\begin{array}{c}0.461^{* * *} \\
(0.009)\end{array}$ & $\begin{array}{c}0.362^{* * *} \\
(0.007)\end{array}$ & $\begin{array}{l}0.296^{* * *} \\
(0.008)\end{array}$ & $\begin{array}{c}0.358^{* * *} \\
(0.007)\end{array}$ & $\begin{array}{c}0.343^{* * *} \\
(0.006)\end{array}$ & $\begin{array}{c}0.360^{* * *} \\
(0.006)\end{array}$ & $\begin{array}{l}0.402^{* * *} \\
(0.006)\end{array}$ & $\begin{array}{c}0.457^{* * *} \\
(0.016)\end{array}$ & $\begin{array}{l}0.497^{* * *} \\
(0.018)\end{array}$ & $\begin{array}{l}0.470^{* * *} \\
(0.016)\end{array}$ & $\begin{array}{l}0.759^{* * *} \\
(0.050)\end{array}$ \\
\hline Large (250+) & $\begin{array}{c}0.733^{* * *} \\
(0.018)\end{array}$ & $\begin{array}{c}0.671^{* * *} \\
(0.014)\end{array}$ & $\begin{array}{c}0.528^{* * *} \\
(0.007)\end{array}$ & $\begin{array}{c}0.473^{* * *} \\
(0.009)\end{array}$ & $\begin{array}{c}0.524^{* * *} \\
(0.007)\end{array}$ & $\begin{array}{c}0.503^{* * *} \\
(0.007)\end{array}$ & $\begin{array}{c}0.527^{* * *} \\
(0.007)\end{array}$ & $\begin{array}{c}0.569^{* * *} \\
(0.007)\end{array}$ & $\begin{array}{c}0.636^{* * *} \\
(0.017)\end{array}$ & $\begin{array}{c}0.663^{* * *} \\
(0.018)\end{array}$ & $\begin{array}{c}0.629^{* * *} \\
(0.019)\end{array}$ & $\begin{array}{c}1.095^{* * *} \\
(0.059)\end{array}$ \\
\hline Small $(10-19) \times$ Market Services & $\begin{array}{c}0.048 \\
(0.031)\end{array}$ & $\begin{array}{l}0.098^{* * *} \\
(0.018)\end{array}$ & $\begin{array}{l}0.059^{* * *} \\
(0.009)\end{array}$ & $\begin{array}{c}0.081^{* * *} \\
(0.010)\end{array}$ & $\begin{array}{c}0.053^{* * *} \\
(0.009)\end{array}$ & $\begin{array}{c}0.057^{* * *} \\
(0.009)\end{array}$ & $\begin{array}{l}0.044^{* * *} \\
(0.009)\end{array}$ & $\begin{array}{c}0.028^{* * *} \\
(0.009)\end{array}$ & $\begin{array}{l}0.048^{*} \\
(0.026)\end{array}$ & $\begin{array}{c}0.010 \\
(0.027)\end{array}$ & $\begin{array}{l}0.087^{* * *} \\
(0.027)\end{array}$ & $\begin{array}{l}0.166^{* *} \\
(0.076)\end{array}$ \\
\hline MediumSmall $(20-49) \times$ Market Services & $\begin{array}{c}0.057 \\
(0.036)\end{array}$ & $\begin{array}{l}0.111^{* * *} \\
(0.020)\end{array}$ & $\begin{array}{c}0.050^{* * *} \\
(0.011)\end{array}$ & $\begin{array}{l}0.102^{* * *} \\
(0.012)\end{array}$ & $\begin{array}{c}0.046^{* * *} \\
(0.011)\end{array}$ & $\begin{array}{c}0.049^{* * *} \\
(0.011)\end{array}$ & $\begin{array}{c}0.032^{* * *} \\
(0.011)\end{array}$ & $\begin{array}{c}0.008 \\
(0.011)\end{array}$ & $\begin{array}{l}0.060^{* *} \\
(0.030)\end{array}$ & $\begin{array}{c}0.040 \\
(0.029)\end{array}$ & $\begin{array}{l}0.081^{* *} \\
(0.033)\end{array}$ & $\begin{array}{l}0.181^{*} \\
(0.103)\end{array}$ \\
\hline Medium $(50-249) \times$ Market Services & $\begin{array}{c}-0.001 \\
(0.041)\end{array}$ & $\begin{array}{l}0.058^{* *} \\
(0.023)\end{array}$ & $\begin{array}{c}-0.011 \\
(0.014)\end{array}$ & $\begin{array}{l}0.056^{* * *} \\
(0.015)\end{array}$ & $\begin{array}{l}-0.013 \\
(0.014)\end{array}$ & $\begin{array}{c}0.001 \\
(0.014)\end{array}$ & $\begin{array}{l}-0.033^{* *} \\
(0.014)\end{array}$ & $\begin{array}{c}-0.073^{* * *} \\
(0.013)\end{array}$ & $\begin{array}{c}0.021 \\
(0.037)\end{array}$ & $\begin{array}{c}0.020 \\
(0.032)\end{array}$ & $\begin{array}{c}0.049 \\
(0.043)\end{array}$ & $\begin{array}{c}0.159 \\
(0.129)\end{array}$ \\
\hline Large $(250+) \times$ Market Services & $\begin{array}{c}-0.195^{* * *} \\
(0.043) \\
\end{array}$ & $\begin{array}{c}-0.180^{* * *} \\
(0.025) \\
\end{array}$ & $\begin{array}{c}-0.179^{* * *} \\
(0.014) \\
\end{array}$ & $\begin{array}{c}-0.103^{* * *} \\
(0.014) \\
\end{array}$ & $\begin{array}{c}-0.181^{* * *} \\
(0.014) \\
\end{array}$ & $\begin{array}{c}-0.166^{* * *} \\
(0.014)\end{array}$ & $\begin{array}{c}-0.186^{* * *} \\
(0.014)\end{array}$ & $\begin{array}{c}-0.227^{* * * *} \\
(0.014) \\
\end{array}$ & $\begin{array}{c}-0.154^{* * * *} \\
(0.039) \\
\end{array}$ & $\begin{array}{c}-0.117^{* * * *} \\
(0.034)\end{array}$ & $\begin{array}{l}-0.100^{* *} \\
(0.047) \\
\end{array}$ & $\begin{array}{l}-0.022 \\
(0.155) \\
\end{array}$ \\
\hline Observations & 18239 & 18239 & 17098 & 17098 & 18021 & 18021 & 16704 & 16704 & 17193 & 17193 & 13878 & 13878 \\
\hline Adj. R-Square & 0.962 & 0.975 & 0.956 & 0.957 & 0.955 & 0.956 & 0.955 & 0.957 & 0.964 & 0.964 & 0.966 & 0.974 \\
\hline $\begin{array}{l}\text { Country-sector-year FE } \\
\text { Num. Countries }\end{array}$ & $\begin{array}{l}\text { Yes } \\
16\end{array}$ & $\begin{array}{l}\text { Yes } \\
16\end{array}$ & $\begin{array}{l}\text { Yes } \\
14\end{array}$ & $\begin{array}{l}\text { Yes } \\
14\end{array}$ & $\begin{array}{l}\text { Yes } \\
14\end{array}$ & $\begin{array}{l}\text { Yes } \\
14\end{array}$ & $\begin{array}{c}\text { Yes } \\
16\end{array}$ & $\begin{array}{l}\text { Yes } \\
16\end{array}$ & $\begin{array}{l}\text { Yes } \\
15\end{array}$ & $\begin{array}{l}\text { Yes } \\
15\end{array}$ & $\begin{array}{l}\text { Yes } \\
12\end{array}$ & $\begin{array}{l}\text { Yes } \\
12\end{array}$ \\
\hline
\end{tabular}


Table A.3. Baseline and robustness of labour productivity by size classes

\begin{tabular}{|c|c|c|c|c|c|c|c|c|c|c|c|c|}
\hline & $\begin{array}{c}\text { (1) } \\
\text { Bas. K-L Ratio }\end{array}$ & $\stackrel{(2)}{\text { K-L Ratio }}$ & $\begin{array}{c}\text { (3) } \\
\text { Bas. H-Skill Sh. }\end{array}$ & $\begin{array}{c}\text { (4) } \\
\text { H-Skill Sh. }\end{array}$ & $\begin{array}{c}\quad \text { (5) } \\
\text { Bas. Soft. Int. }\end{array}$ & $\begin{array}{c}\text { (6) } \\
\text { Soft. Int. }\end{array}$ & $\begin{array}{l}\text { (7) } \\
\text { Bas. R\&D. Int. }\end{array}$ & $\begin{array}{c}(8) \\
\text { R\&D. Int. }\end{array}$ & $\begin{array}{c}\text { (9) } \\
\text { Bas. HHI }\end{array}$ & $\begin{array}{l}(10) \\
\mathrm{HHI}\end{array}$ & $\begin{array}{l}(11) \\
\text { Bas. Firm Age }\end{array}$ & $\begin{array}{c}(12) \\
\text { Firm Age }\end{array}$ \\
\hline Small (10-19) & $\begin{array}{c}0.219^{* * *} \\
(0.006)\end{array}$ & $\begin{array}{c}0.222^{* * *} \\
(0.004)\end{array}$ & $\begin{array}{c}0.137^{* * *} \\
(0.008)\end{array}$ & $\begin{array}{c}0.039^{* * *} \\
(0.005)\end{array}$ & $\begin{array}{c}0.142^{* * *} \\
(0.008)\end{array}$ & $\begin{array}{l}0.135^{* * *} \\
(0.007)\end{array}$ & $\begin{array}{c}0.138^{* * *} \\
(0.008)\end{array}$ & $\begin{array}{c}0.149^{* * *} \\
(0.007)\end{array}$ & $\begin{array}{c}0.090^{* * *} \\
(0.006)\end{array}$ & $\begin{array}{l}0.105^{* * *} \\
(0.005)\end{array}$ & $\begin{array}{l}0.152^{* * *} \\
(0.009)\end{array}$ & $\begin{array}{c}0.012 \\
(0.012)\end{array}$ \\
\hline MediumSmall (20-49) & $\begin{array}{c}0.336^{* * *} \\
(0.008)\end{array}$ & $\begin{array}{l}0.281^{* * *} \\
(0.005)\end{array}$ & $\begin{array}{l}0.243^{* * *} \\
(0.010)\end{array}$ & $\begin{array}{c}0.109^{* * *} \\
(0.008)\end{array}$ & $\begin{array}{c}0.248^{* * *} \\
(0.010)\end{array}$ & $\begin{array}{l}0.238^{* * *} \\
(0.008)\end{array}$ & $\begin{array}{c}0.243^{* * *} \\
(0.009)\end{array}$ & $\begin{array}{c}0.258^{* * *} \\
(0.008)\end{array}$ & $\begin{array}{c}0.173^{* * *} \\
(0.007)\end{array}$ & $\begin{array}{l}0.184^{* * *} \\
(0.006)\end{array}$ & $\begin{array}{c}0.261^{* * *} \\
(0.011)\end{array}$ & $\begin{array}{l}0.072^{* * *} \\
(0.015)\end{array}$ \\
\hline Medium (50-249) & $\begin{array}{l}0.473^{* * *} \\
(0.010)\end{array}$ & $\begin{array}{c}0.336^{* * *} \\
(0.008)\end{array}$ & $\begin{array}{l}0.365^{* * *} \\
(0.011)\end{array}$ & $\begin{array}{l}0.204^{* * *} \\
(0.010)\end{array}$ & $\begin{array}{c}0.368^{* * *} \\
(0.011)\end{array}$ & $\begin{array}{l}0.350^{* * *} \\
(0.009)\end{array}$ & $\begin{array}{l}0.364^{* * *} \\
(0.011)\end{array}$ & $\begin{array}{l}0.394^{* * *} \\
(0.010)\end{array}$ & $\begin{array}{c}0.284^{* * *} \\
(0.008)\end{array}$ & $\begin{array}{l}0.292^{* * *} \\
(0.007)\end{array}$ & $\begin{array}{c}0.392^{* * *} \\
(0.013)\end{array}$ & $\begin{array}{l}0.189^{* * *} \\
(0.018)\end{array}$ \\
\hline Large (250+) & $\begin{array}{l}0.697^{* * *} \\
(0.009)\end{array}$ & $\begin{array}{l}0.436^{* * *} \\
(0.014)\end{array}$ & $\begin{array}{l}0.573^{* * *} \\
(0.011)\end{array}$ & $\begin{array}{l}0.431^{* * *} \\
(0.010)\end{array}$ & $\begin{array}{c}0.578^{* * *} \\
(0.011)\end{array}$ & $\begin{array}{l}0.553^{* * *} \\
(0.010)\end{array}$ & $\begin{array}{l}0.573^{* * *} \\
(0.011)\end{array}$ & $\begin{array}{l}0.594^{* * *} \\
(0.010)\end{array}$ & $\begin{array}{l}0.518^{* * *} \\
(0.009)\end{array}$ & $\begin{array}{l}0.532^{* * *} \\
(0.008)\end{array}$ & $\begin{array}{c}0.599^{* * *} \\
(0.013)\end{array}$ & $\begin{array}{l}0.422^{* * *} \\
(0.023)\end{array}$ \\
\hline Small $(10-19) \times$ Market Services & $\begin{array}{l}-0.004 \\
(0.017)\end{array}$ & $\begin{array}{c}0.014 \\
(0.012)\end{array}$ & $\begin{array}{c}0.015 \\
(0.013)\end{array}$ & $\begin{array}{l}0.112^{* * *} \\
(0.010)\end{array}$ & $\begin{array}{c}0.009 \\
(0.013)\end{array}$ & $\begin{array}{c}0.018 \\
(0.013)\end{array}$ & $\begin{array}{l}0.023^{*} \\
(0.014)\end{array}$ & $\begin{array}{c}0.015 \\
(0.014)\end{array}$ & $\begin{array}{l}0.032^{* *} \\
(0.014)\end{array}$ & $\begin{array}{c}-0.054^{* * *} \\
(0.014)\end{array}$ & $\begin{array}{l}0.056^{* * *} \\
(0.018)\end{array}$ & $\begin{array}{c}0.070 \\
(0.043)\end{array}$ \\
\hline MediumSmall (20-49) $\times$ Market Services & $\begin{array}{c}-0.066^{* * *} \\
(0.020)\end{array}$ & $\begin{array}{c}0.014 \\
(0.013)\end{array}$ & $\begin{array}{c}-0.048^{* * *} \\
(0.015)\end{array}$ & $\begin{array}{c}0.088^{* * *} \\
(0.013)\end{array}$ & $\begin{array}{c}-0.052^{* * *} \\
(0.015)\end{array}$ & $\begin{array}{c}-0.043^{* * *} \\
(0.014)\end{array}$ & $\begin{array}{l}-0.038^{* *} \\
(0.015)\end{array}$ & $\begin{array}{c}-0.050^{* * *} \\
(0.015)\end{array}$ & $\begin{array}{l}-0.004 \\
(0.015)\end{array}$ & $\begin{array}{c}-0.064^{* * *} \\
(0.015)\end{array}$ & $\begin{array}{l}-0.006 \\
(0.021)\end{array}$ & $\begin{array}{c}0.044 \\
(0.058)\end{array}$ \\
\hline Medium (50-249) $\times$ Market Services & $\begin{array}{c}-0.210^{* * *} \\
(0.024)\end{array}$ & $\begin{array}{l}-0.017 \\
(0.015)\end{array}$ & $\begin{array}{c}-0.163^{* * *} \\
(0.018)\end{array}$ & $\begin{array}{c}0.011 \\
(0.016)\end{array}$ & $\begin{array}{c}-0.167^{* * *} \\
(0.018)\end{array}$ & $\begin{array}{c}-0.155^{* * *} \\
(0.018)\end{array}$ & $\begin{array}{c}-0.158^{* * * *} \\
(0.019)\end{array}$ & $\begin{array}{c}-0.186^{* * *} \\
(0.019)\end{array}$ & $\begin{array}{c}-0.113^{* * *} \\
(0.020)\end{array}$ & $\begin{array}{c}-0.129^{* * *} \\
(0.016)\end{array}$ & $\begin{array}{c}-0.102^{* * *} \\
(0.025)\end{array}$ & $\begin{array}{l}-0.053 \\
(0.072)\end{array}$ \\
\hline Large $(250+) \times$ Market Services & $\begin{array}{c}-0.488^{* * * *} \\
(0.030)\end{array}$ & $\begin{array}{c}-0.192^{* * * *} \\
(0.020)\end{array}$ & $\begin{array}{c}-0.386^{* * *} \\
(0.024)\end{array}$ & $\begin{array}{c}-0.207^{* * *} \\
(0.021)\end{array}$ & $\begin{array}{c}-0.389^{* * *} \\
(0.024)\end{array}$ & $\begin{array}{c}-0.381^{* * *} \\
(0.024)\end{array}$ & $\begin{array}{c}-0.377^{* * * *} \\
(0.027)\end{array}$ & $\begin{array}{c}-0.398^{* * *} \\
(0.027)\end{array}$ & $\begin{array}{c}-0.388^{* * * *} \\
(0.026)\end{array}$ & $\begin{array}{c}-0.319^{* * *} \\
(0.019)\end{array}$ & $\begin{array}{c}-0.323^{* * *} \\
(0.027)\end{array}$ & $\begin{array}{c}-0.352^{* * * *} \\
(0.088)\end{array}$ \\
\hline Observations & 18042 & 18042 & 16908 & 16908 & 17824 & 17824 & 16514 & 16514 & 17005 & 17005 & 13874 & 13874 \\
\hline Adj. R-Square & 0.960 & 0.975 & 0.951 & 0.960 & 0.951 & 0.953 & 0.944 & 0.945 & 0.970 & 0.971 & 0.966 & 0.971 \\
\hline Country-sector-year FE & Yes & Yes & Yes & Yes & Yes & Yes & Yes & Yes & Yes & Yes & Yes & Yes \\
\hline Num. Countries & 16 & 16 & 14 & 14 & 14 & 14 & 16 & 16 & 15 & 15 & 12 & 12 \\
\hline
\end{tabular}

Clustered standard errors at the country-sector-year level in parentheses: $p<0.1, ", p<0.05$,

Table A.4. Baseline and robustness of multi-factor productivity by size classes

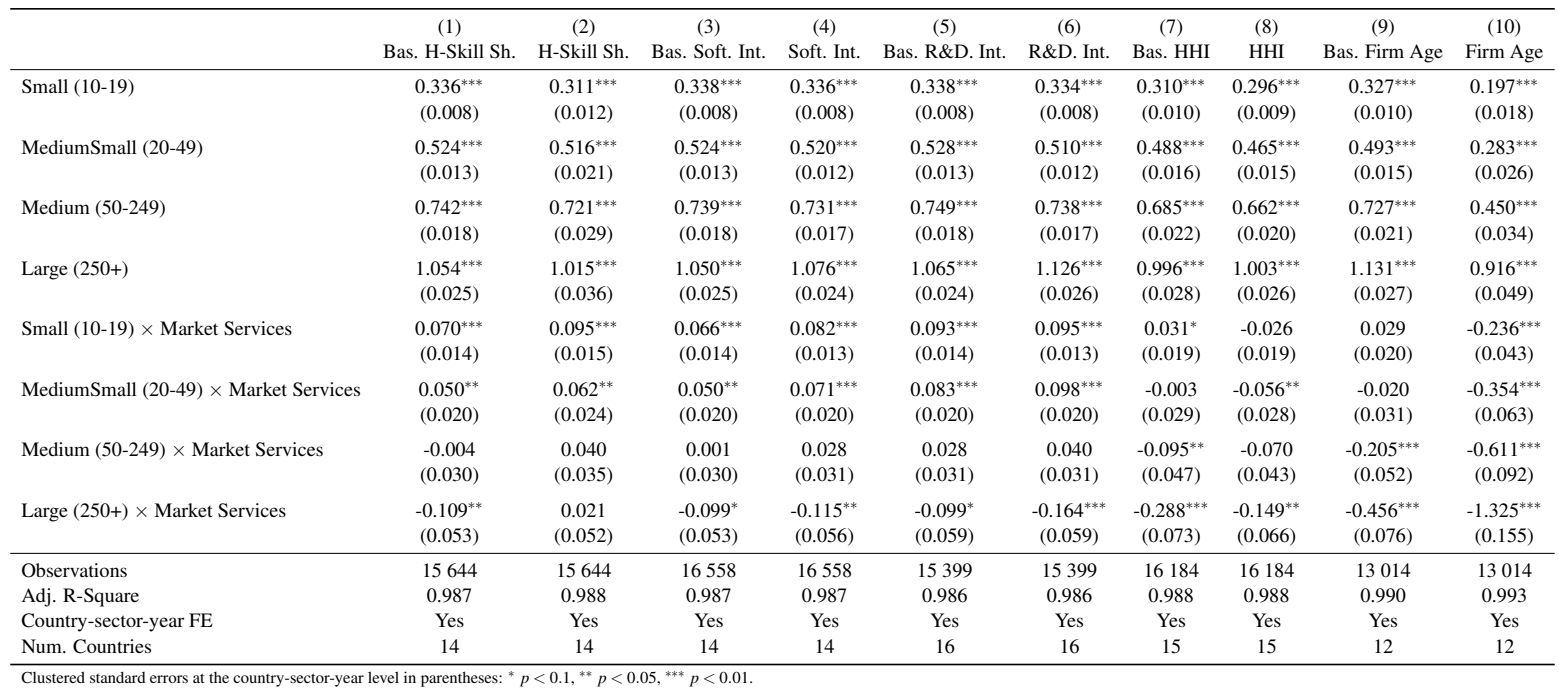

The set of countries include:AUT,BEL,CHL,DNK,FRA,HUN,ITA,JPN,NLD,NOR,PRT,SWE. 
Table A.5. Coefficient for large (250+) service firms by 2-digit sector

\begin{tabular}{lccc}
\hline 2-Digit Sector & Wages & LP & MFP \\
\hline Advertising and market research & - & - & - \\
Administrative and support service activities & - & - & - \\
Legal and accounting activities & - & - & - \\
Accommodation and food service activities & - & - & + \\
Transportation and storage & 0 & - & - \\
IT and other information services & 0 & - & - \\
Wholesale and retail trade & 0 & - & 0 \\
Publishing, audiovisual and broadcasting & 0 & 0 & - \\
Scientific research and development & 0 & 0 & + \\
Telecommunications & + & + & + \\
\hline
\end{tabular}

Note: We perform regressions in the same fashion of Equation (5), but keeping only one 2-digit service sector at the time. The table reports the signs of the average size-wage and size-productivity differentials for large firms in each 2-digit service sector with respect to large firms in manufacturing (corresponding to the last raw of Table 3 ). The value 0 corresponds to not significant coefficients.

Table A.6. Wages by productivity quantiles, manufacturing vs. services

\begin{tabular}{lcccc}
\hline & $(1)$ & $(2)$ & $(3)$ & $(4)$ \\
& $\ln ($ LP) Manuf & $\ln ($ LP) Serv & $\ln ($ MFP_W) Manuf. & $\ln ($ MFP_W) Serv \\
\hline p10-p40 & $0.529^{* * *}$ & $0.643^{* * *}$ & $0.487^{* * *}$ & $0.540^{* * *}$ \\
& $(0.007)$ & $(0.009)$ & $(0.008)$ & $(0.008)$ \\
p40-p60 & $0.803^{* * *}$ & $1.028^{* * *}$ & $0.734^{* * *}$ & $0.843^{* * *}$ \\
& $(0.011)$ & $(0.016)$ & $(0.011)$ & $(0.011)$ \\
p60-p90 & $1.008^{* * *}$ & $1.334^{* * *}$ & $0.928^{* * *}$ & $1.101^{* * *}$ \\
& $(0.012)$ & $(0.022)$ & $(0.012)$ & $(0.012)$ \\
p90-p100 & $1.309^{* * *}$ & $1.805^{* * *}$ & $1.173^{* * *}$ & $1.468^{* * *}$ \\
& $(0.013)$ & $(0.031)$ & $(0.012)$ & $(0.014)$ \\
\hline Observations & 11019 & 9089 & 10699 & 8642 \\
Adj. R-Square & 0.974 & 0.968 & 0.975 & 0.979 \\
Country-sector year FE & YES & YES & YES & YES \\
Num. Countries & 17 & 17 & 17 & 17 \\
\hline Clustered standard errors at the country-sector-year level in parentheses: ${ }^{*} p<0.1,{ }^{* *} p<0.05,{ }^{* * *} p<0.01$. \\
The set of countries include:AUS,AUT,BEL,CAN,CHE,CHL,DEU,DNK,FIN,FRA,HUN,ITA,JPN,NLD,NOR,PRT,SWE.
\end{tabular}


Figure A.4. Wages by gross output quantiles

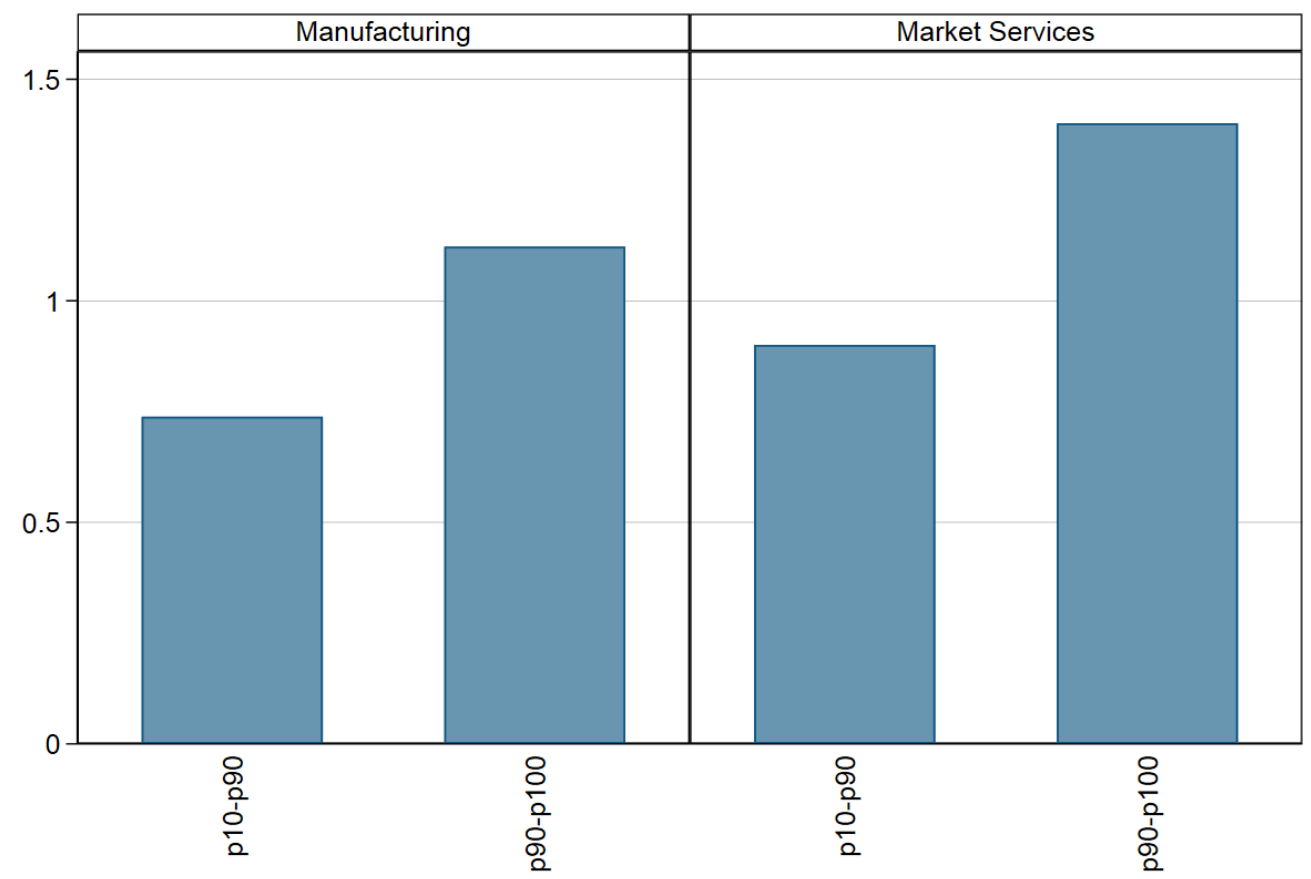

Note: The figure plots the estimated gross output dummies of a regression of log-wages within country-sector pairs and years. In particular, he gross output distribution has been split into 3 bins: $1^{\text {st }}$ to $10^{\text {th }}$ percentile, $10^{\text {th }}$ to $90^{\text {th }}$, and $90^{\text {th }}$ to $100^{\text {th }}$. Data used include the following countries: AUS, AUT, BEL, CAN, CHE, CHL, DEU,DNK, FIN, FRA, HUN, ITA, JPN, NLD, NOR, PRT, SWE.

Table A.7. Wages by gross output quantiles

\begin{tabular}{lcc}
\hline & $(1)$ & $(2)$ \\
& $\ln (\mathrm{W})$ & $\ln (\mathrm{W})$ \\
\hline $10 \_90$ & $0.738^{* * *}$ & $0.739^{* * *}$ \\
& $(0.016)$ & $(0.016)$ \\
$90 \_100$ & $1.122^{* * *}$ & $1.122^{* * *}$ \\
& $(0.024)$ & $(0.024)$ \\
$10 \_90 \times$ Market Services & $0.162^{* * *}$ & $0.162^{* * *}$ \\
& $(0.030)$ & $(0.029)$ \\
$90 \_100 \times$ Market Services & $0.278^{* * *}$ & $0.278^{* * *}$ \\
& $(0.053)$ & $(0.052)$ \\
\hline Observations & 12717 & 12668 \\
Adj. R-Square & 0.961 & 0.947 \\
Country-sector Year FE & YES & YES \\
Country-sector-year FE & & 17 \\
Num. Countries & 17 & \\
\hline Clustered standard errors at the country-sector-year level in parentheses: ${ }^{*} p<0.1,{ }^{* *} p<0.05,{ }^{* * *} p<0.01$. \\
The set of countries include:AUS,AUT,BEL,CAN,CHE,CHL,DEU,DNK,FIN,FRA,HUN,ITA,JPN,NLD,NOR,PRT,SWE.
\end{tabular}


Table A.8. Baseline and robustness of wages by LP quantiles

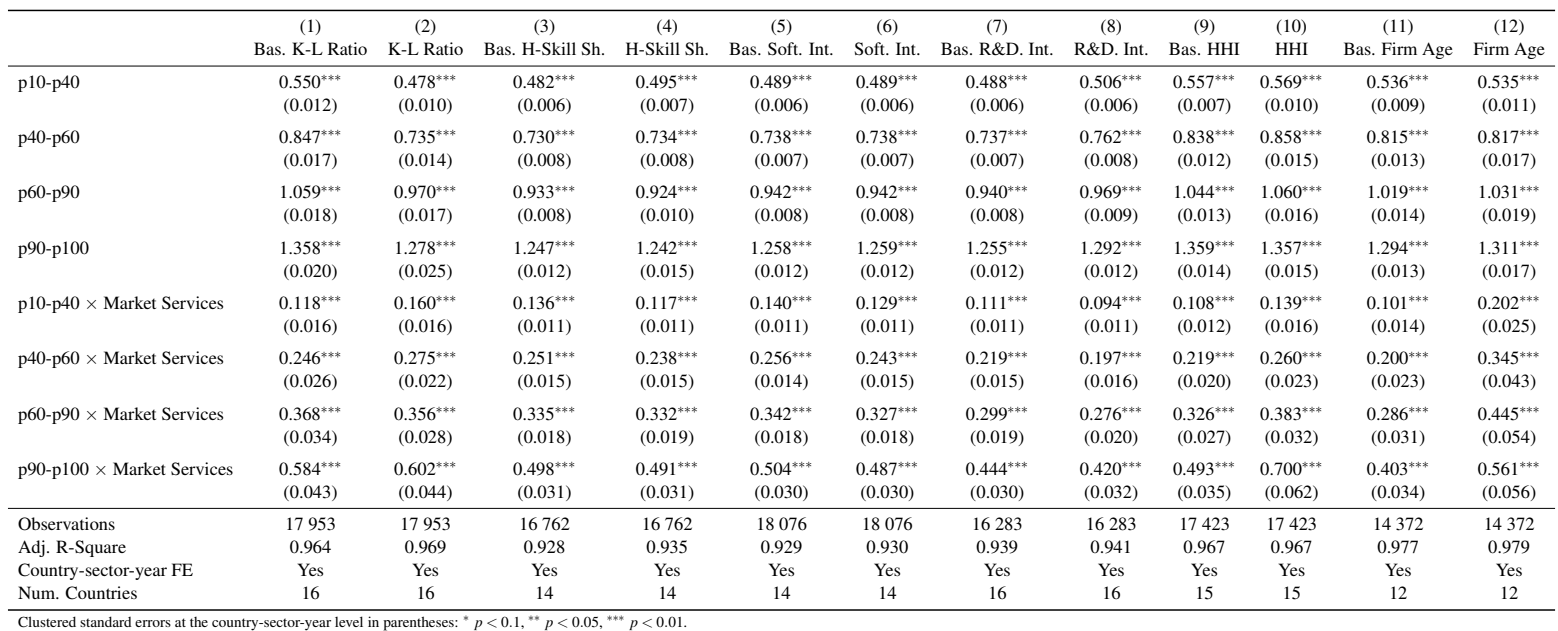

Clustered standard errors at the country-sector-year level in parentheses: $p<0.1, \cdots p<0.05$,
The set of countries include:AUT,BEL,CHL,DNK,FRA,HUN,ITA,JPN,NLD,NOR,PRT,SWE

Table A.9. Baseline and robustness of wages by MFP quantiles

\begin{tabular}{|c|c|c|c|c|c|c|c|c|c|c|c|c|}
\hline & $\begin{array}{c}\text { (1) } \\
\text { Bas. K-L Ratio }\end{array}$ & $\begin{array}{c}(2) \\
\text { K-L Ratio }\end{array}$ & $\begin{array}{l}\text { (3) } \\
\text { Bas. H-Skill Sh. }\end{array}$ & $\begin{array}{c}\text { (4) } \\
\text { H-Skill Sh. }\end{array}$ & $\begin{array}{l}\stackrel{(5)}{ } \\
\text { Bas. Soft. Int. }\end{array}$ & $\begin{array}{c}\text { (6) } \\
\text { Soft. Int. }\end{array}$ & $\begin{array}{c}\text { (7) } \\
\text { Bas. R\&D. Int. }\end{array}$ & $\begin{array}{l}\text { (8) } \\
\text { R\&D. Int. }\end{array}$ & $\begin{array}{c}(9) \\
\text { Bas. HHI }\end{array}$ & $\begin{array}{l}(10) \\
\mathrm{HHI}\end{array}$ & $\begin{array}{l}(11) \\
\text { Bas. Firm Age }\end{array}$ & $\begin{array}{l}(12) \\
\text { Firm Age }\end{array}$ \\
\hline p10-p40 & $\begin{array}{c}0.456^{* * *} \\
(0.012)\end{array}$ & $\begin{array}{c}0.447^{* * *} \\
(0.007)\end{array}$ & $\begin{array}{c}0.438^{* * *} \\
(0.008)\end{array}$ & $\begin{array}{l}0.456^{* * *} \\
(0.008)\end{array}$ & $\begin{array}{l}0.445^{* * *} \\
(0.007)\end{array}$ & $\begin{array}{l}0.446^{* * *} \\
(0.007)\end{array}$ & $\begin{array}{l}0.445^{* * *} \\
(0.007)\end{array}$ & $\begin{array}{l}0.461^{* * *} \\
(0.007)\end{array}$ & $\begin{array}{l}0.512^{* * *} \\
(0.008)\end{array}$ & $\begin{array}{l}0.513^{* * *} \\
(0.010)\end{array}$ & $\begin{array}{c}0.525^{* * *} \\
(0.009)\end{array}$ & $\begin{array}{c}0.491^{* * *} \\
(0.009)\end{array}$ \\
\hline p40-p60 & $\begin{array}{l}0.703^{* * *} \\
(0.017)\end{array}$ & $\begin{array}{l}0.685^{* * *} \\
(0.009)\end{array}$ & $\begin{array}{c}0.666^{* * *} \\
(0.010)\end{array}$ & $\begin{array}{c}0.681^{* * *} \\
(0.011)\end{array}$ & $\begin{array}{l}0.673^{* * *} \\
(0.009)\end{array}$ & $\begin{array}{l}0.676^{* * *} \\
(0.009)\end{array}$ & $\begin{array}{l}0.673^{* * *} \\
(0.009)\end{array}$ & $\begin{array}{l}0.695^{* * *} \\
(0.009)\end{array}$ & $\begin{array}{l}0.764^{* * *} \\
(0.011)\end{array}$ & $\begin{array}{l}0.764^{* * *} \\
(0.014)\end{array}$ & $\begin{array}{l}0.785^{* * *} \\
(0.012)\end{array}$ & $\begin{array}{c}0.736^{* * *} \\
(0.014)\end{array}$ \\
\hline p60-p90 & $\begin{array}{l}0.894^{* * *} \\
(0.017)\end{array}$ & $\begin{array}{c}0.874^{* * *} \\
(0.010)\end{array}$ & $\begin{array}{c}0.863^{* * *} \\
(0.011)\end{array}$ & $\begin{array}{l}0.862^{* * *} \\
(0.014)\end{array}$ & $\begin{array}{c}0.870^{* * *} \\
(0.011)\end{array}$ & $\begin{array}{l}0.872^{* * *} \\
(0.010)\end{array}$ & $\begin{array}{c}0.871^{* * *} \\
(0.011)\end{array}$ & $\begin{array}{l}0.899^{* * *} \\
(0.011)\end{array}$ & $\begin{array}{c}0.955^{* * *} \\
(0.013)\end{array}$ & $\begin{array}{l}0.948^{* * *} \\
(0.014)\end{array}$ & $\begin{array}{c}0.982^{* * *} \\
(0.013)\end{array}$ & $\begin{array}{c}0.921^{* * *} \\
(0.016)\end{array}$ \\
\hline p90-p100 & $\begin{array}{l}1.147^{* * *} \\
(0.017)\end{array}$ & $\begin{array}{l}1.126^{* * *} \\
(0.013)\end{array}$ & $\begin{array}{l}1.119^{* * *} \\
(0.012)\end{array}$ & $\begin{array}{l}1.106^{* * *} \\
(0.017)\end{array}$ & $\begin{array}{l}1.127^{* * *} \\
(0.011)\end{array}$ & $\begin{array}{l}1.129^{* * *} \\
(0.011)\end{array}$ & $\begin{array}{l}1.127^{* * *} \\
(0.011)\end{array}$ & $\begin{array}{l}1.160^{* * *} \\
(0.012)\end{array}$ & $\begin{array}{l}1.189^{* * *} \\
(0.013)\end{array}$ & $\begin{array}{l}1.159^{* * *} \\
(0.014)\end{array}$ & $\begin{array}{l}1.215^{* * *} \\
(0.013)\end{array}$ & $\begin{array}{l}1.140^{* * *} \\
(0.018)\end{array}$ \\
\hline p10-p40 × Market Services & $\begin{array}{l}0.033^{* *} \\
(0.015)\end{array}$ & $\begin{array}{l}0.070^{* * *} \\
(0.012)\end{array}$ & $\begin{array}{l}0.100^{* * *} \\
(0.012)\end{array}$ & $\begin{array}{l}0.077^{* * *} \\
(0.012)\end{array}$ & $\begin{array}{l}0.103^{* * *} \\
(0.011)\end{array}$ & $\begin{array}{l}0.094^{* * *} \\
(0.012)\end{array}$ & $\begin{array}{l}0.080^{* * *} \\
(0.012)\end{array}$ & $\begin{array}{l}0.060^{* * *} \\
(0.012)\end{array}$ & $\begin{array}{l}0.045^{* * *} \\
(0.011)\end{array}$ & $\begin{array}{c}0.006 \\
(0.014)\end{array}$ & $\begin{array}{l}0.058^{* * *} \\
(0.012)\end{array}$ & $\begin{array}{l}0.065^{* * *} \\
(0.018)\end{array}$ \\
\hline p40-p60 × Market Services & $\begin{array}{l}0.073^{* * *} \\
(0.022)\end{array}$ & $\begin{array}{c}0.157^{* * *} \\
(0.016)\end{array}$ & $\begin{array}{l}0.191^{* * *} \\
(0.014)\end{array}$ & $\begin{array}{l}0.168^{* * *} \\
(0.016)\end{array}$ & $\begin{array}{c}0.195^{* * *} \\
(0.014)\end{array}$ & $\begin{array}{l}0.183^{* * *} \\
(0.015)\end{array}$ & $\begin{array}{l}0.166^{* * *} \\
(0.015)\end{array}$ & $\begin{array}{l}0.141^{* * *} \\
(0.015)\end{array}$ & $\begin{array}{l}0.100^{* * *} \\
(0.016)\end{array}$ & $\begin{array}{l}0.041^{* *} \\
(0.020)\end{array}$ & $\begin{array}{l}0.110^{* * *} \\
(0.018)\end{array}$ & $\begin{array}{l}0.117^{* * *} \\
(0.028)\end{array}$ \\
\hline p60-p90 × Market Services & $\begin{array}{c}0.144^{* * *} \\
(0.023)\end{array}$ & $\begin{array}{c}0.235^{* * *} \\
(0.018)\end{array}$ & $\begin{array}{c}0.252^{* * *} \\
(0.016)\end{array}$ & $\begin{array}{c}0.244^{* * *} \\
(0.018)\end{array}$ & $\begin{array}{c}0.258^{* * *} \\
(0.016)\end{array}$ & $\begin{array}{c}0.245^{* * *} \\
(0.016)\end{array}$ & $\begin{array}{c}0.228^{* * *} \\
(0.016)\end{array}$ & $\begin{array}{c}0.200^{* * *} \\
(0.016)\end{array}$ & $\begin{array}{c}0.169^{* * *} \\
(0.017)\end{array}$ & $\begin{array}{c}0.113^{* * *} \\
(0.023)\end{array}$ & $\begin{array}{c}0.173^{* * *} \\
(0.019)\end{array}$ & $\begin{array}{c}0.176^{* * *} \\
(0.033)\end{array}$ \\
\hline p90-p100 × Market Services & $\begin{array}{l}0.277^{* * *} \\
(0.027) \\
\end{array}$ & $\begin{array}{l}0.363^{* * *} \\
(0.026) \\
\end{array}$ & $\begin{array}{c}0.368^{* * *} \\
(0.018) \\
\end{array}$ & $\begin{array}{l}0.373^{* * *} \\
(0.021)\end{array}$ & $\begin{array}{l}0.374^{* * *} \\
(0.018) \\
\end{array}$ & $\begin{array}{c}0.351^{* * *} \\
(0.018)\end{array}$ & $\begin{array}{c}0.337^{* * *} \\
(0.019) \\
\end{array}$ & $\begin{array}{c}0.315^{* * *} \\
(0.018) \\
\end{array}$ & $\begin{array}{l}0.302^{* * *} \\
(0.020)\end{array}$ & $\begin{array}{l}0.297^{* * *} \\
(0.032) \\
\end{array}$ & $\begin{array}{l}0.264^{* * *} \\
(0.020) \\
\end{array}$ & $\begin{array}{c}0.267^{* * *} \\
(0.037) \\
\end{array}$ \\
\hline Observations & 17356 & 17356 & 16266 & 16266 & 17267 & 17267 & 15732 & 15732 & 17053 & 17053 & 13489 & 13489 \\
\hline Adj. R-Square & 0.975 & 0.980 & 0.943 & 0.946 & 0.942 & 0.943 & 0.945 & 0.948 & 0.978 & 0.978 & 0.984 & 0.984 \\
\hline Country-sector-year FE & Yes & Yes & Yes & Yes & Yes & Yes & Yes & Yes & Yes & Yes & Yes & Yes \\
\hline Num. Countries & 16 & 16 & 14 & 14 & 14 & 14 & 16 & 16 & 15 & 15 & 12 & 12 \\
\hline
\end{tabular}

